\title{
European Journal of Inorganic Chemistry
}

\author{
Reduction of $\left(\mathrm{C}_{5} \mathrm{Me}_{5}\right)_{2} \mathrm{Mo}_{2} \mathrm{O}_{5}$ and $\left(\mathrm{C}_{5} \mathrm{Me}_{5}\right)_{2} \mathrm{Mo}_{2} \mathrm{O}_{4}$ in Methanol - Water - \\ Trifluoroacetate Solutions investigated by Combined On-Line \\ Electrochemistry/Electrospray Mass Spectrometry.
}

Jenny Gun ${ }^{[a]}$ Alexandre Modestov, ${ }^{[a]}$ Ovadia Lev ${ }^{[a]}$ and Rinaldo Poli*[b]

${ }^{[a]}$ Lab Environmental Chemistry, The Casali Inst, The Inst. Of Chem., The Hebrew University of Jerusalem, Jerusalem 91904, Israel

Fax: +972-2-6586155

E-mail: gunjen@pob.huji.ac.il

${ }^{[b]}$ Laboratoire de Synthèse et d'Electrosynthèse Organométalliques, Faculté des Sciences "Gabriel", Université de Bourgogne, 6 Boulevard Gabriel, 21000 Dijon, France

Fax: $+33-380393720$

E-mail: poli@u-bourgogne.fr

Received (will be filled in by the editorial staff)

Molybdenum/ Oxo ligands / Cyclopentadienyl ligands / Electrospray ionisation mass spectrometry / Electrochemistry 
Complexes $\mathrm{Cp}_{2}{ }_{2} \mathrm{Mo}_{2} \mathrm{O}_{5}\left(\mathrm{Cp}^{*}=\eta^{5}-\mathrm{C}_{5} \mathrm{Me}_{5}\right)$ and $\mathrm{Cp}^{*}{ }_{2} \mathrm{Mo}_{2} \mathrm{O}_{4}$ were investigated by combined on-line electrochemical (EC) reduction and electrospray ionisation mass spectrometry (ESIMS) in an trifluoroacetic acid-buffered water - methanol solution. It is shown that the reduction products at the larger negative potentials are identical for both compounds. The studies reveal the existence of a wide class of previously unknown bi- and trinuclear $\mathrm{Mo}^{\mathrm{V}}$, $\mathrm{Mo}^{\mathrm{IV}}, \mathrm{Mo}^{\mathrm{III}}$ and mixed-valence complexes which were identified on the basis of their masses and characteristic isotope patterns. The structures of the initial compounds and the $m / z=713$ 729 product of electroreduction were supported by in-situ $\mathrm{MS}^{\mathrm{n}}$ experiments with the elucidation of the fragmentation pathway for the collision induced dissociation. 


\section{Introduction}

The development of the Electrospray Ionization Mass Spectrometers (ESI-MS) by Yamashita and Fenn ${ }^{[1]}$ has provided a very powerful technique for analyzing various charged inorganic, ${ }^{[2]}$ organic $^{[3]}$ and organometallic species in solution. ${ }^{[4]}$ Electrospray is an atmospheric pressure technique that makes use of an electrostatic sprayer to assist the transfer of the ionic analytes that are initially present in solution into the gas phase. ${ }^{[5]}$ In contrast to conventional ionization methods which create undesirable fragment ions, the ESI technique usually gives simpler spectra. ${ }^{[6]}$

The on-line combination of electrochemistry with ESI-MS has been an achievement of the very last decade. The preparative electrochemistry, followed by ESI-MS analysis of the isolated products or products generated in situ have been extensively explored by Bond $e t$ $a l .{ }^{[7,8]}$ Three other groups, Cole et al.,${ }^{[9,10]}$ Van Berkel et al., ${ }^{[11,12]}$ and Brajter-Toth et al.. ${ }^{[13]}$ used an electrochemical cell coupled on-line with mass spectrometry for the investigation of redox reactions.

In our previous publication which focused only on the reductive process of compound $\mathrm{Cp}^{*}{ }_{2} \mathrm{Mo}_{2} \mathrm{O}_{5},{ }^{[14]}$ we have shown how, from the analytical point of view, various operating conditions may be optimized in order to minimize spurious reactions in the electrospray chamber and obtain spectra that reflect the solution composition. The previous study was carried out in an acetic-buffered solution and most of the resulting reduction products were found to incorporate the acetate ligand. A subsequent chemical reduction study has allowed the isolation and structural characterization of compound $\left[\mathrm{Cp} * \mathrm{MoO}\left(\mathrm{O}_{2} \mathrm{CCH}_{3}\right)\right]_{2}$, which is closely related to one of the species observed by EC-ESI-MS. ${ }^{[15]}$ With the goal of generating more reactive aqua species and to reach the lower oxidation states of Mo, we have expanded the previous study to solutions containing the stronger trifluoroacetic acid, whose 
conjugate base has a poorer coordinating ability. In order to verify the electroreduction pathway of the compound $\left(\mathrm{C}_{5} \mathrm{Me}_{5}\right)_{2} \mathrm{Mo}_{2} \mathrm{O}_{5}$ we have expanded the electroreduction experiments to the previously described ${ }^{[16-18]} \mathrm{Mo}(\mathrm{V})$ compound $\left(\mathrm{C}_{5} \mathrm{Me}_{5}\right)_{2} \mathrm{Mo}_{2} \mathrm{O}_{4}$.

Experiments on sequential product ion fragmentations $\left(\mathrm{MS}^{\mathrm{n}}\right)$ by collision induced dissociation (CID) were performed in order to elucidate the gas phase degradation pathway for the starting and product compounds. In general, low energy CID is a powerful technique due to the simplicity and reliability of performing sequential ion fragmentation $\mathrm{MS}^{\mathrm{n}}$ experiments. Collisions between analyte ions and helium gas that serves as a damping buffer gas in the ion trap are used for analyte ion fragmentations and excitations. Collision-induced decomposition produces ionic and neutral species simultaneously in the ion trap. However, only the charged species can be directly identified in conventional multistage mass spectrometry. The chemical structure of the neutral species can only be hypothesized on the basis of the most favored fragmentation mechanisms. Valuable information on the molecular structures of organic compounds has also been acquired by ESI-MS ${ }^{\text {n }}$ but very few investigations have been conducted for the organometallic compounds. ${ }^{[19,20]}$

\section{Results and Discussion}

\section{Positive mode ESI-MS spectrum of the starting compounds.}

The positive mode ESI-MS spectra of the starting compounds are shown in Figure 1, frames A and B. The inserts show the characteristic isotopic patterns of mono-, di- and trinuclear Mo fragments. For mononuclear Mo species, the isotopic envelope consists of 7 lines with two gaps located between the first and second and between the sixth and seventh lines, respectively. The isotopic envelope of a dinuclear Mo ion consists of 14 peaks and has a width of $16 \mathrm{~m} / \mathrm{z}$ units, while that of a trinuclear Mo species has width of $23 \mathrm{~m} / \mathrm{z}$ units The width of the isotopic envelope is an important characteristic in our $\mathrm{MS}^{\mathrm{n}}$ fragmentation experiments for the perfect isolation of the whole set of the molecules with the same structure. We shall refer to the various species by the $m / z$ value of the full isotopic pattern in the 
isotopic distribution and will compare it to the calculated distributions ${ }^{[21]}$ for the molecular assignment.

$<$ Figure 1>

Spectrum A was measured for a water - methanol solution of $\mathrm{Cp}_{2}{ }_{2} \mathrm{Mo}_{2} \mathrm{O}_{5}$ containing 0.1 $M$ trifluoroacetic acid. It reveals three major regions of peaks, corresponding to mono-, diand trinuclear species, respectively. The ESI-MS spectrum of this compound in water methanol containing $0.1 \mathrm{M}$ ammonium acetate $(\mathrm{pH}=4)$ has been previously described. ${ }^{[14]}$ The lower $\mathrm{pH}(\mathrm{pH}=1.8)$ used in the present study changes significantly the product distribution in every region. The mononuclear region exhibits the $\mathrm{Cp}^{*} \mathrm{MoO}_{2}{ }^{+}$peak $(\mathrm{m} / \mathrm{z}=$ 259-267) and the $\mathrm{Cp}^{*} \mathrm{MoO}_{3} \mathrm{H}_{2}{ }^{+}$peak $(\mathrm{m} / \mathrm{z}=277-285)$ at approximately the same relative intensity as in the previous acetate buffer study. The strongest peak, however, corresponds to the methanol addition product, $\mathrm{Cp}^{*} \mathrm{MoO}_{2}(\mathrm{MeOH})^{+}(m / z=291-299)$, which had only a very small intensity in the acetic buffer. The formation of adducts with solvent molecules in the ion trap is a well known phenomenon. ${ }^{[22,23]}$

The main peak for dinuclear species corresponds to the protonated starting compound $\mathrm{Cp}_{2}{ }_{2} \mathrm{Mo}_{2} \mathrm{O}_{5} \mathrm{H}^{+}(m / z=535-551)$, as in the corresponding acetic buffer study. ${ }^{[14]}$ The other most pronounced dinuclear peaks, corresponding to daughter ions formed in the ESI-MS chamber, had not been previously described, since their intensity was much lower under the higher $\mathrm{pH}$ conditions. They increase in relative abundance at increasing heated capillary temperatures. The lighter one $(\mathrm{m} / \mathrm{z}=517-533)$ corresponds to loss of one water molecule. This process must of course involve at least one of the $\mathrm{Cp}^{*}$ methyl $\mathrm{H}$ atoms, leading to a tetramethylfulvene ligand. Therefore, the peak is assigned to complex $\mathrm{Cp} *\left(\mathrm{C}_{4} \mathrm{Me}_{4} \mathrm{CH}_{2}\right) \mathrm{Mo}_{2} \mathrm{O}_{4}{ }^{+}$. The methylene group of this ligand may be bonded to the molybdenum atom or to one of the oxygen atoms. The envelope at higher masses, on the 
other hand, results from the superposition of two envelopes, one (major) at $\mathrm{m} / \mathrm{z}=549-565$ which is attributed to a $\mathrm{MeOH}$ adduct of the just described tetramethylfulvene complex, and one (minor) at $\mathrm{m} / \mathrm{z}=553-569$ probably resulting from water addition to the starting compound. The $\mathrm{Cp}^{*}{ }_{3} \mathrm{Mo}_{3} \mathrm{O}_{7}{ }^{+}$peak $(m / z=793-816)$ is the only relevant feature in the trinuclear species region.

The differences between Figure 1 and the corresponding spectrum resulting from the acetic buffer experiment (see Figure 1 of ref. [14]) are consistent with our parallel speciation studies. We have shown that complex $\mathrm{Cp}^{*} \mathrm{MoO}_{2}{ }^{+}$is the predominant species at $\mathrm{pH}<\mathrm{ca} .3$, while a mixture of $\mathrm{Cp}^{*} \mathrm{MoO}_{2}{ }^{+}$and $\mathrm{Cp}^{*} \mathrm{MoO}_{3}{ }^{-}$(in equilibrium with $\mathrm{Cp}^{*} \mathrm{MoO}_{2}(\mathrm{OH}$ ) and $\mathrm{Cp}_{2}{ }_{2} \mathrm{Mo}_{2} \mathrm{O}_{5}$ depending on the $\mathrm{H}_{2} \mathrm{O}: \mathrm{MeOH}$ ratio) is present at $\mathrm{pH}$ ca. $4{ }^{\left[{ }^{[2]}\right]}$ Indeed, the peaks related to the dinuclear $\mathrm{Cp}^{*}{ }_{2} \mathrm{Mo}_{2} \mathrm{O}_{5}$ species are less abundant at the lower $\mathrm{pH}$, while all those related to species $\mathrm{Cp}^{*} \mathrm{MoO}_{2}{ }^{+}$(mononuclear and trinuclear species) are comparatively more abundant. Indeed, the trinuclear species results from the addition of $\mathrm{Cp}^{*} \mathrm{MoO}_{2}^{+}$to $\mathrm{Cp}_{2}{ }_{2} \mathrm{Mo}_{2} \mathrm{O}_{5}$ (vide infra).

The ESI-MS investigation of complex $\mathrm{Cp}^{*}{ }_{2} \mathrm{Mo}_{2} \mathrm{O}_{4}$, reported here for the first time, was carried out under the same conditions used for compound $\mathrm{Cp}^{*}{ }_{2} \mathrm{Mo}_{2} \mathrm{O}_{5}$, for comparison reasons. The spectrum of the starting solution is shown in Frame B of Figure 1. The main peak corresponds to the protonated starting compound, $\left(\mathrm{C}_{5} \mathrm{Me}_{5}\right)_{2} \mathrm{Mo}_{2} \mathrm{O}_{4} \mathrm{H}^{+}(m / z=519-535)$, and the second most important component $(m / z=1058-1085)$ is assigned to the tetranuclear $\mathrm{Cp}_{4}{ }_{4} \mathrm{Mo}_{4} \mathrm{O}_{6}(\mathrm{OH})_{3}{ }^{+}$complex. The latter is formally obtained by dimerization of the starting compound and addition of a water molecule and a proton. Evidence for the existence of a tetranuclear species has been provided for the corresponding Cp system. ${ }^{[25]}$ The spectrum shows fewer peaks relative to that of the pentaoxo analogue. This can result from either a simpler solution composition (the speciation of this compound in methanol-water is yet unknown) or from a greater gas phase stability and therefore a less pronounced collision- 
induced decomposition. Both compounds adopt a neutral molecular structure in organic solvents. ${ }^{[16,26]}$ In order to further explore this point, we proceeded with a detailed investigation of gas phase stability and $\mathrm{MS}^{\mathrm{n}}$ fragmentation pathways of the starting compounds.

\section{Gas phase stability of the starting compounds}

Figure 2 shows the relative abundance of the starting compound peaks $(\mathrm{m} / \mathrm{z}=535-551$ for $\mathrm{Cp}^{*}{ }_{2} \mathrm{Mo}_{2} \mathrm{O}_{5} \mathrm{H}^{+}$and $m / z=519-535$ for $\mathrm{Cp}^{*}{ }_{2} \mathrm{Mo}_{2} \mathrm{O}_{4} \mathrm{H}^{+}$as a function of the applied collision energy during the collision activated decomposition events in the ion trap mass spectrometer. Both dissociation profiles lead to S-shaped curves. The half wave collision energy $\left(\mathrm{E}_{1 / 2}\right)$ corresponds to the energy (in the percentage of the maximum tickling voltage) at which the relative abundance in fraction of the total ion current of the starting ion is $0.5 .{ }^{[27-30]}$ For the same charge state $(+1)$, the larger the $\mathrm{E}_{1 / 2}$ value the more stable the compound in the gas phase. As it is evident from Figure 2, the $\mathrm{E}_{1 / 2}$ of $\mathrm{Cp}^{*}{ }_{2} \mathrm{Mo}_{2} \mathrm{O}_{4}$ is almost twice the $\mathrm{E}_{1 / 2}$ of $\mathrm{Cp}^{*}{ }_{2} \mathrm{Mo}_{2} \mathrm{O}_{5}$, underscoring the greater gas-phase stability of the former compound. This difference can be rather easily rationalized on the basis of the known structural and bonding differences between the two compounds. While the tetraoxo $\mathrm{Mo}(\mathrm{V})$ complex contains a direct metalmetal bond and two oxo bridges, the pentaoxo compound contains one oxo bridge and no metal-metal interaction.

$<$ Figure 2>

\section{Fragmentation pathways of the starting compounds}

The dissociation profiles provided us with information about the stability of $\mathrm{Cp}_{2}{ }_{2} \mathrm{Mo}_{2} \mathrm{O}_{5}$ and $\mathrm{Cp}^{*}{ }_{2} \mathrm{Mo}_{2} \mathrm{O}_{4}$ complexes in the ion trap. An analysis of their degradation in the ion trap was carried out by their isolation therein followed by the observation of their sequential 
multistep dissociation $\left(\mathrm{MS}^{\mathrm{n}}\right.$ experiments). The main results for $\mathrm{Cp}_{2}{ }_{2} \mathrm{Mo}_{2} \mathrm{O}_{5}$ and $\mathrm{Cp}^{*}{ }_{2} \mathrm{Mo}_{2} \mathrm{O}_{4}$ are shown in frames $\mathrm{A}$ and $\mathrm{B}$ of Figure 3, with the proposed fragmentation pathways in Scheme 1 and Scheme 2, respectively.

\section{$<$ Figure 3>}

$\langle$ Scheme 1>

$<$ Scheme 2>

As concluded above from the dissociation profiles, $\mathrm{Cp}^{*}{ }_{2} \mathrm{Mo}_{2} \mathrm{O}_{5}$ is less stable than $\mathrm{Cp}_{2}{ }_{2} \mathrm{Mo}_{2} \mathrm{O}_{4}$ in the ion trap. The spectrum in Figure 3A shows that the first CID step for the $\mathrm{Cp}^{*}{ }_{2} \mathrm{Mo}_{2} \mathrm{O}_{5} \mathrm{H}^{+}$ion generates only one daughter ion $(\mathrm{m} / \mathrm{z}=517-533)$ by loss of a water molecule. $\mathrm{MS}^{3}$ fragmentation of this daughter ion leads to many products by further loss of water and of a neutral dioxo(fulvene)molybdenum fragment. To the best of our knowledge, the $\mathrm{C}-\mathrm{H}$ activation of a $\mathrm{Cp}^{*}$ methyl group which is associated to the elimination of a water molecule and to the transformation to a tetramethylfulvene ligand has not previously been highlighted for an MS study. There is, however, at least one precedent in solution chemistry for compound $\left[\mathrm{Cp}^{*} \mathrm{RuCl}_{2}\right]_{2} \mathrm{O} .^{[31]}$

The main peaks are tentatively assigned in Scheme 1, though it is not possible to establish the exact methyl group that furnishes the hydrogen atoms. The $m / z=359-367$ peak has the characteristic shape of a monomolybdenum species and is not observed at all in the regular ESI-MS. -This compound would results from the elimination of a molybdic acid molecule with abstraction of two $\mathrm{H}$ atoms from the $\mathrm{Cp}^{*}$ methyl groups. This assignment is in further agreement with related fragmentations or more reduced species, as will be shown later. It must be further pointed out that the exact structure of the proposed species containing two or more activated $\mathrm{Me}$ groups, e.g. $\left[\left(\mathrm{C}_{5} \mathrm{Me}_{4} \mathrm{CH}_{2}\right)_{2} \mathrm{Mo}\right]^{+}$or $\left[\left\{\mathrm{C}_{5} \mathrm{Me}_{2}\left(\mathrm{CH}_{2}\right)_{3}\right\}\left\{\mathrm{C}_{5} \mathrm{Me}_{3}\left(\mathrm{CH}_{2}\right)_{2}\right\} \mathrm{Mo}_{2} \mathrm{O}\right]^{+}$, may implicate formation of $\mathrm{C}-\mathrm{C}$ bonds or $\mathrm{C}-\mathrm{O}$ bonds.

The CID of complex $\left(\mathrm{C}_{5} \mathrm{Me}_{5}\right)_{2} \mathrm{Mo}_{2} \mathrm{O}_{4}$ gives fewer peaks than its pentaoxo analogue. Most dinuclear peaks are related for the two compounds (16 fewer mass units corresponding to one oxygen atom). The main mononuclear peak $(\mathrm{m} / \mathrm{z}=360-369)$ is one mass unit higher than the main mononuclear peak derived from the pentaoxo solution, thus indicating that it is 
a one-electron reduced form of it. It probably derives from the explusion of a $\mathrm{MoO}(\mathrm{OH})_{3}$ species from the parent dinuclear $\operatorname{Mo}(\mathrm{V})$ complex, paralleling exactly the formation of the mononuclear species in Scheme 1 .

\section{Electrochemical experiments}

Figure 4 shows the voltammogram recorded in our flow-through electrochemical cell in parallel with the ESI-MS measurements. Curve A shows the background voltammogram, whereas curves $\mathrm{B}$ and $\mathrm{C}$ show the voltammograms of the $\mathrm{Cp}^{*}{ }_{2} \mathrm{Mo}_{2} \mathrm{O}_{4}$ and $\mathrm{Cp}_{2}{ }_{2} \mathrm{Mo}_{2} \mathrm{O}_{5}$ solutions, respectively. As the Mo concentration is identical for both solutions, any difference between curves $\mathrm{B}$ and $\mathrm{C}$ must be attributed to the difference in Mo oxidation state in the starting compound. This assumption is supported by the volt-spectrogram of $\mathrm{Cp}_{2}{ }_{2} \mathrm{Mo}_{2} \mathrm{O}_{5}$ (vide infra), which clearly indicates that the electroreduction of $\mathrm{Cp}_{2}{ }_{2} \mathrm{Mo}_{2} \mathrm{O}_{5}$ goes through the formation of $\mathrm{Cp}_{2}{ }_{2} \mathrm{Mo}_{2} \mathrm{O}_{4}$.

The current - potential curves at the forward and backward scans go in parallel for both compounds and the heights are virtually scan rate independent over a rather wide range of scan rates (up to $100 \mathrm{mV} \mathrm{s}^{-1}$ ). This means that the electrochemical reduction of both $\mathrm{Cp}_{2}{ }_{2} \mathrm{Mo}_{2} \mathrm{O}_{4}$ and $\mathrm{Cp}_{2}{ }_{2} \mathrm{Mo}_{2} \mathrm{O}_{5}$ is apparently controlled by an interfacial step rather than being diffusion limited. In separate studies that are out of the scope of the present paper, we have witnessed the formation of a polymer film on the electrode surface under the electroreduction conditions. This makes the elucidation of the $\mathrm{Cp}_{2}{ }_{2} \mathrm{Mo}_{2} \mathrm{O}_{4}$ and $\mathrm{Cp}_{2}{ }_{2} \mathrm{Mo}_{2} \mathrm{O}_{5}$ electroreduction mechanisms and the identification of the electroreduction products impossible tasks solely on the basis of the voltammetric experiments.

$<$ Figure 4> 


\section{Coupled electrochemistry - ESI-MS studies: consumption of the starting species}

The coupled EC/ESI-MS study was carried out with a slow $(0.5 \mathrm{mV} / \mathrm{s})$ linear potential sweep between 0 and $-1 \mathrm{~V}$ and back to 0 , similar to the experiment described in our previous study. ${ }^{[14]}$ Figure 5 shows the volt-spectrograms of the major mono-, di-, and trinuclear species. During the backward, anodic scan, the concentration profiles follow approximately the same pattern observed in the cathodic scan, indicating that the experiment is not polluted by film deposition processes.

$<$ Figure 5>

The concentrations of both mononuclear species and of the dinuclear species start to decrease at a potential slightly less negative than $E=-0.5 \mathrm{~V}$. The trinuclear species, on the other hand, decreases in concentration much earlier, at ca. $E=0$, and reaches a minimum at $E$ $=-0.5 \mathrm{~V}$. This result unambiguously shows that the trinuclear species must be already present in solution. If it had formed by combination of $\mathrm{Cp}^{*} \mathrm{MoO}_{2}{ }^{+}$and $\mathrm{Cp}^{*}{ }_{2} \mathrm{Mo}_{2} \mathrm{O}_{5}$ only in the spectrometer chamber, its abundance would not decrease prior to that of either of the two other species. The reduction of the trinuclear species is thermodynamically easier than those of the mono- and dinuclear species, probably because of the metal-metal bond formation which is expected to accompany the process (vide infra). Since we have shown that a waterrich environment favors the spontaneous ionization of $\mathrm{Cp}^{*}{ }_{2} \mathrm{Mo}_{2} \mathrm{O}_{5}$ into $\mathrm{Cp}^{*} \mathrm{MoO}_{2}{ }^{+}$and $\mathrm{Cp}^{*} \mathrm{MoO}_{3}{ }^{-}$, we propose that the trinuclear species equally derives from the combination of $\mathrm{Cp}^{*} \mathrm{MoO}_{3}{ }^{-}$with two $\mathrm{Cp}^{*} \mathrm{MoO}_{2}{ }^{+}$ions, as shown in Scheme 3.

$<$ Scheme 3> 


\section{Electrochemical formation of reduced dimer compounds}

Figure 6 shows the mass spectrum of the $\mathrm{Cp}^{*}{ }_{2} \mathrm{Mo}_{2} \mathrm{O}_{5}$ solution recorded at $-1 \mathrm{~V}$. Several new peaks, assigned to electroreduction products, are evident in this spectrum. Some of these peaks are associated with reduction products that are identical with or related to those previously observed under the same conditions in an acetic buffer $\left(\right.$ i.e. $\mathrm{Cp}^{*}{ }_{2} \mathrm{Mo}_{2} \mathrm{O}_{4} \mathrm{H}^{+}, \mathrm{m} / \mathrm{z}=$ 519-535). Other peaks, on the other hand, correspond to new species (i.e. $\mathrm{Cp}_{2}{ }_{2} \mathrm{Mo}_{2}(\mathrm{OH})\left(\mathrm{O}_{2} \mathrm{CCF}_{3}\right)_{2}{ }^{+}, \quad m / z=697-715 ; \mathrm{Cp}^{*}{ }_{2} \mathrm{Mo}_{2} \mathrm{O}(\mathrm{OH})\left(\mathrm{O}_{2} \mathrm{CF}_{3}\right)_{2}{ }^{+}, \quad m / z=713-729 ;$ $\left.\mathrm{Cp}_{2}{ }_{2} \mathrm{Mo}_{2} \mathrm{O}_{3}\left(\mathrm{O}_{2} \mathrm{CCF}_{3}\right)^{+}, m / z=615-633\right)$. The nature and the intensity/potential profiles of all electroreduction products obtained from the $\mathrm{Cp}^{*}{ }_{2} \mathrm{Mo}_{2} \mathrm{O}_{4}$ solution are identical with those deriving from the pentaoxo solution. This indicates that all reduced products obtained from the pentaoxo solution form through the intermediacy of the tetraoxo complex.

$<$ Figure 6>

Figure 7 depicts volt-spectrograms of a few selected reduced dinuclear products, namely two $\mathrm{Mo}_{2}{ }^{\mathrm{V}, \mathrm{V}}$ species, $\left[\mathrm{Cp}^{*}{ }_{2} \mathrm{Mo}_{2} \mathrm{O}_{4} \mathrm{H}\right]^{+}$and $\left[\mathrm{Cp}^{*}{ }_{2} \mathrm{Mo}_{2} \mathrm{O}_{3}\left(\mathrm{O}_{2} \mathrm{CCF}_{3}\right)\right]^{+}$, a Mo ${ }^{\mathrm{IV}, \mathrm{IV}}$ species, $\left[\mathrm{Cp}_{2}{ }_{2} \mathrm{Mo}_{2} \mathrm{O}(\mathrm{OH})\left(\mathrm{O}_{2} \mathrm{CCF}_{3}\right)_{2}\right]^{+}$, and a $\mathrm{Mo}_{2}{ }^{\mathrm{III}, \mathrm{III}}$ species, $\left[\mathrm{Cp}^{*}{ }_{2} \mathrm{Mo}_{2}(\mathrm{OH})\left(\mathrm{O}_{2} \mathrm{CCF}_{3}\right)_{2}\right]^{+}$, together with their corresponding MS isotopic pattern and a tentatively assigned structure. Interestingly, the major electroreduction products observed in the current study derive from subsequent 2-electron additions, whereas the previous acetic buffer study also showed a dinuclear mixed-valence $\left(\mathrm{Mo}_{2}{ }^{\mathrm{IV}, \mathrm{V}}\right)$ species. Mononuclear $\mathrm{Mo}^{\mathrm{V}}$ and $\mathrm{Mo}^{\mathrm{IV}}$ acetato complexes where also evident in the previous study, whereas corresponding trifluoroacetato species are not observed in the present investigation.

Another notable difference is that whereas the observed $\mathrm{Mo}_{2}{ }^{\mathrm{V}, \mathrm{V}}$ products have the same stoichiometry under both conditions, the $\mathrm{Mo}_{2}{ }^{\mathrm{IV}, \mathrm{IV}}$ product is $\mathrm{Cp}_{2}^{*} \mathrm{Mo}_{2}(\mathrm{O})(\mathrm{OH})\left(\mathrm{O}_{2} \mathrm{CCF}_{3}\right)_{2}{ }^{+}$in 
the present study and $\mathrm{Cp}_{2}{ }_{2} \mathrm{Mo}_{2} \mathrm{O}\left(\mathrm{O}_{2} \mathrm{CCH}_{3}\right)_{3}{ }^{+}$in the previous acetate study. A peak for the corresponding $\mathrm{Cp}_{2}{ }_{2} \mathrm{Mo}_{2} \mathrm{O}\left(\mathrm{O}_{2} \mathrm{CCF}_{3}\right)_{3}{ }^{+}$ion is not observed in the present study. This seems counterintuitive, because the stronger trifluoroacetic acid should be better capable to replace the hydroxo ligand. A possible, though somewhat speculative interpretation, relies on two fundamental differences between the two acids and the corresponding conjugate bases: while $\mathrm{CF}_{3} \mathrm{COOH}$ is the stronger acid, $\mathrm{CH}_{3} \mathrm{COO}^{-}$is the better coordinating agent. Thus, reduction of the same $\mathrm{Cp}_{2}{ }_{2} \mathrm{Mo}_{2} \mathrm{O}_{3}\left(\mathrm{O}_{2} \mathrm{CCX}_{3}\right)^{+}\left(\mathrm{Mo}_{2}{ }^{\mathrm{V}, \mathrm{V}} ; \mathrm{X}=\mathrm{H}, \mathrm{F}\right)$ complex would lead to the same $\mathrm{Cp}_{2}{ }_{2} \mathrm{Mo}_{2} \mathrm{O}_{2}\left(\mathrm{O}_{2} \mathrm{CCX}_{3}\right)_{2}{ }^{+}\left(\mathrm{Mo}_{2}{ }^{\mathrm{IV}, \mathrm{V}}\right)$ ion according to Scheme 4. This, however, would only be observed for the acetato system because the stronger $\mathrm{CF}_{3} \mathrm{COOH}$ acid would immediately protonate it. The $\mathrm{CH}_{3} \mathrm{COOH}$ system could, on the other hand, lead to a triacetato species because of the stronger coordinating properties of the acetate ion. If this hypothesis holds true, each final $\mathrm{Mo}_{2}{ }^{\mathrm{IV}, \mathrm{IV}}$ product would be observed merely because the exchange process between hydroxide and (trifluoro)acetate, though thermodynamically favorable, is too slow under the present conditions. It is also worth mentioning that the neutral diacetato compound $\mathrm{Cp}_{2}{ }_{2} \mathrm{Mo}_{2} \mathrm{O}_{2}\left(\mathrm{O}_{2} \mathrm{CCH}_{3}\right)_{2}$ (i.e. a deprotonated version of the observed product for the trifluoroacetato system) has been isolated from a reductive chemical synthesis and crystallographically characterized. ${ }^{[15]}$

$<$ Figure 7>

While the electroreduction did not afford any dinuclear ion with oxidation states below IV when carried out in an acetic buffer, it also provides a $\mathrm{Mo}_{2}{ }^{\mathrm{III}, \mathrm{III}}$ complex in the presence of trifluoroacetic acid. This difference may again be attributed to the stronger acidic properties of $\mathrm{CF}_{3} \mathrm{COOH}$, favoring the protonation of the oxo ligands and their removal as water molecules. 
$<$ Scheme 4>

The following approximate potential values for the appearance of every dinuclear reduced species may be measured on the volt-spectrograms in Figure 7: $\mathrm{Cp}^{*}{ }_{2} \mathrm{Mo}_{2} \mathrm{O}_{4} \mathrm{H}^{+}$ $\left(\mathrm{Mo}_{2}{ }^{\mathrm{V}, \mathrm{V}}\right),-0.55 \mathrm{~V} ; \mathrm{Cp}^{*}{ }_{2} \mathrm{Mo}_{2} \mathrm{O}_{3}\left(\mathrm{O}_{2} \mathrm{CCF}_{3}\right)^{+}\left(\mathrm{Mo}_{2}{ }^{\mathrm{V}, \mathrm{V}}\right),-0.60 \mathrm{~V} ; \mathrm{Cp}_{2}{ }_{2} \mathrm{Mo}_{2}(\mathrm{O})(\mathrm{OH})\left(\mathrm{O}_{2} \mathrm{CCF}_{3}\right)_{2}{ }^{+}$ $\left(\mathrm{Mo}_{2}{ }^{\mathrm{IV}, \mathrm{IV}}\right),-0.68 \mathrm{~V} ; \mathrm{Cp}^{*}{ }_{2} \mathrm{Mo}_{2} \mathrm{O}\left(\mathrm{O}_{2} \mathrm{CCF}_{3}\right)_{2}{ }^{+}\left(\mathrm{Mo}_{2}{ }^{\mathrm{III}, \mathrm{III}}\right),-0.76 \mathrm{~V}$. A comparison of the onset reduction potentials with those observed in the previous acetate study is useful. The $\mathrm{Cp}^{*}{ }_{2} \mathrm{Mo}_{2} \mathrm{O}_{4} \mathrm{H}^{+}$product is not acid dependent. In both studies, the onset of this peak is at approximately the same potential as the onset for the $\mathrm{Cp}^{*}{ }_{2} \mathrm{Mo}_{2} \mathrm{O}_{5} \mathrm{H}^{+}$consumption and the two numerical values are quite similar (these numbers may be measured only with limited precision). The $\left[\mathrm{Cp}^{*}{ }_{2} \mathrm{Mo}_{2} \mathrm{O}_{3}\left(\mathrm{O}_{2} \mathrm{CCF}_{3}\right)\right]^{+} \mathrm{Mo}_{2}{ }^{\mathrm{V}, \mathrm{V}}$ species starts to form at a more negative potential relative to the acetato analogue $(-0.55 \mathrm{~V})$. Further reduction to the $\mathrm{Mo}_{2}{ }^{\mathrm{IV}, \mathrm{IV}}$ species seems easier for the trifluoroacetato system, in agreement with expectations $(c f .-0.74 \mathrm{~V}$ and $-0.78 \mathrm{~V}$ for the acetato $\mathrm{Mo}_{2}{ }^{\mathrm{IV}, \mathrm{V}}$ and $\mathrm{Mo}_{2}{ }^{\mathrm{IV}, \mathrm{IV}}$ products, respectively). Furthermore, reduction to the $\mathrm{Mo}_{2}{ }^{\mathrm{III}, \mathrm{III}}$ product starts at an even lower potential, while this process is not observed for the acetato system, as mentioned above.

\section{Structural elucidation of the $m / z=713-729$ product.}

The main product of both $\mathrm{Cp}^{*}{ }_{2} \mathrm{Mo}_{2} \mathrm{O}_{5}$ and $\mathrm{Cp}^{*}{ }_{2} \mathrm{Mo}_{2} \mathrm{O}_{4}$ electroreductions, namely the $\mathrm{Mo}_{2}{ }^{\mathrm{IV}, \mathrm{IV}}$ ion interpreted as $\mathrm{Cp}^{*}{ }_{2} \mathrm{Mo}_{2} \mathrm{O}(\mathrm{OH})\left(\mathrm{O}_{2} \mathrm{CCF}_{3}\right)_{2}{ }^{+}$, was the subject of more detailed $\mathrm{MS}^{\mathrm{n}}$ studies. There are two reasons for this choice. First, we wanted to prove the general approach of our product identification. Second, we wanted to check whether any observed peaks are in fact attributable to daughter ions of this major peak rather than to primary products of the electrochemical reduction. 
Figure 8 shows the main results of the $\mathrm{MS}^{\mathrm{n}}$ experiment. The spectrum shown in part A is produced from the isolation of the species at $m / z=713-729$ and subsequent CID. There are four main daughter ion products, the main one being that with $m / z=599-615$. In fact, the lighter products increase in subsequent $\mathrm{MS}^{\mathrm{n}}$ experiments, while the heavier one (32 mass units higher) is obviously the solvent (methanol) adduct formed by gas-phase reactions in the ion trap. ${ }^{[28]}$ This assignment is further supported by the next $\mathrm{MS}^{\mathrm{n}}$ step. The $m / z=599-615$ product ion was isolated and consequently subjected to further collision activation $\left(\mathrm{MS}^{3}\right)$, giving the spectrum shown in Figure 8B. The further generation of the 634-650 peak can be easily understood in terms of the solvent adduct formation. Additional fragmentation by CID $\left(\mathrm{MS}^{4}\right)$ of the product ion with $\mathrm{m} / z=502-518$ results in one main product with $\mathrm{m} / \mathrm{z}=485-501$ and a mononuclear peak with $m / z=361-369$ ), see Figure 8C.

$<$ Figure 8>

The proposed product ion compositions and fragmentation pathways are shown in Scheme 5. The first fragment $(\mathrm{m} / z=599-615)$ results from the loss of 114 units, which correspond to the molecular weight of trifluoroacetic acid. Therefore, this fragment is still a dinuclear compound of $\mathrm{Mo}^{\mathrm{IV}}$. Under the conditions of the experiment (CID $=30 \%$ for every $\mathrm{MS}^{\mathrm{n}}$ step) the next step of the fragmentation results in a prominent peak with the loss of 97 units, corresponding to a trifluoroacetyl group, and a minor peak with the loss of an additional 17 units $(\mathrm{OH})$. The latter peak becomes the prominent one in the $\mathrm{MS}^{4}$. Loss of the acetyl group results in a formal oxidation to a mixed-valence $\mathrm{Mo}_{2}{ }^{\mathrm{IV}, \mathrm{V}}$ ion which is not observed under the electroreduction conditions, whereas the subsequent $\mathrm{OH}$ loss gives back a $\mathrm{Mo}_{2}{ }^{\mathrm{IV}, \mathrm{IV}}$ ion. The $\mathrm{OH}$ and the $\mathrm{MoO}_{2}(\mathrm{OH})$ expulsion processes must involve one of the $\mathrm{Cp}^{*}$ methyl protons yielding a tetramethylfulvene ligand, as already observed above for the CID of the 
starting complexes. It is quite interesting to observe that, for the three fragmentation processes leading from dinuclear to mononuclear species with loss of a neutral inorganic Mo complex, the latter always corresponds to an oxide/hydroxide in the highest possible oxidation state, i.e. $\mathrm{Mo}^{\mathrm{VI}}$ from $\mathrm{Mo}_{2}{ }^{\mathrm{VI}, \mathrm{VI}}$ (Scheme 1), $\mathrm{Mo}^{\mathrm{V}}$ from $\mathrm{Mo}_{2}{ }^{\mathrm{V}, \mathrm{V}}$ (Scheme 2) and $\mathrm{Mo}^{\mathrm{V}}$ from $\mathrm{Mo}_{2}{ }^{\mathrm{IV}, \mathrm{V}}$ (Scheme 5).

It can be concluded from Scheme 5 that the fragmentation pathway undertaken by the $m / z=713-729$ compound is similar to that of the starting compounds. It is noteworthy that the $m / z=485$ and 361 peaks generated by $\mathrm{MS}^{4}$ are related to the fragments obtained from the $\mathrm{Mo}^{\mathrm{VI}}$ precursor $(m / z=481$ and 359 , see Figure $3 \mathrm{~A})$ and to those obtained from the $\mathrm{Mo}^{\mathrm{V}}$ precursor $(\mathrm{m} / \mathrm{z}=483$ and 360, see Figure 3B). Therefore, these mass values further support the notion that the $m / z$ 713-729 ion corresponds to a $\mathrm{Mo}_{2}{ }^{\mathrm{IV}, \mathrm{IV}}$ complex.

$<$ Scheme 5>

\section{Electrochemical formation of reduced trinuclear species}

As can be seen by comparing Figure 1 and Figure 6 there are prominent spectral changes in the trinuclear $\mathrm{m} / \mathrm{z}$ region following the electrochemical reduction. Voltspectrograms of the reduced trinuclear compounds are present in Figure 9. Because of overlap between the isotopic envelopes of different trinuclear species, the volt-spectrogram integrations were carried out over limited $\mathrm{m} / \mathrm{z}$ ranges rather than over the entire envelope. The ranges used for the integrations are marked in the figure. As for the previous acetic buffer study, the envelope of the reduced trinuclear species is shifted exactly by 16 units to lower $m / z$ relative to its precursor complex $\mathrm{Cp}^{*}{ }_{3} \mathrm{Mo}_{3} \mathrm{O}_{7}{ }^{+}$, suggesting its formulation as a proton-free hexaoxo species. In contrast to the previous acetic buffer study, on the other hand, further reduction occurs by successive oxygen atom removal steps, resulting in the observation of 
$\mathrm{Cp}_{3}{ }_{3} \mathrm{Mo}_{3} \mathrm{O}_{6}{ }^{+}\left(\mathrm{Mo}_{3}{ }^{\mathrm{V}, \mathrm{V}, \mathrm{VI}}\right), \quad \mathrm{Cp}_{3}{ }_{3} \mathrm{Mo}_{3} \mathrm{O}_{5}{ }^{+}\left(\mathrm{Mo}_{3}{ }^{\mathrm{IV}, \mathrm{V}, \mathrm{V}}\right)$ and $\mathrm{Cp}_{3}{ }_{3} \mathrm{Mo}_{3} \mathrm{O}_{4}{ }^{+}\left(\mathrm{Mo}_{3}{ }^{\mathrm{IV}, \mathrm{IV}, \mathrm{IV}}\right)$. Once again, this behavior can be attributed to the stronger acidity of $\mathrm{CF}_{3} \mathrm{COOH}$. As for the dinuclear products discussed above, the formation of the trinuclear species in trifluoroacetic acid takes place through 2-electron transfer steps and the reduction potential becomes more negative as the oxidation state decreases. The onset potential values for the various reduced species, as measured from the volt-spectrograms in Figure 9, are $-0.54 \mathrm{~V} ;-0.61 \mathrm{~V}$ and -0.75 $\mathrm{V}$, in order of decreasing number of oxygen atoms.

$<$ Figure 9>

The structures assigned to various reduced species are only tentative and were drawn on the basis of the maximum symmetry principle. A $\left[\left(\mathrm{Cp}^{*} \mathrm{Mo}\right)_{3}(\mu-\mathrm{O})_{6}\right]$ core has been shown to exist in complex $\left[(\mathrm{Cp} * \mathrm{Mo})_{3}\left(\mu_{2}-\mathrm{OH}\right)_{n}\left(\mu_{2}-\mathrm{O}\right)_{6-n}\right]^{2+}$ (the value of $\mathrm{n}$, probably 5 , was not clearly established in the X-ray study ${ }^{[32]}$ and in related $\mathrm{Cp}^{*}{ }_{4} \mathrm{Mo}_{5} \mathrm{O}_{11}$ and $\mathrm{Cp}^{*}{ }_{6} \mathrm{Mo}_{8} \mathrm{O}_{16}$ clusters. ${ }^{[32,33]}$ The oxidation state in these $\mathrm{Mo}_{3} \mathrm{O}_{6}$ cores, however, is lower $\left(\mathrm{Mo}_{3}{ }^{11+}-\mathrm{Mo}_{3}{ }^{14+}\right)$. The dicapped $\mathrm{Mo}_{3}\left(\mu_{3}-\mathrm{O}\right)_{2}\left(\mu_{2}-\mathrm{O}\right)_{3}$ unit is quite common in inorganic clusters but has not been found as yet, to the best of our knowledge, for $\mathrm{Cp}^{*}$-substituted triangular clusters of any metal. Finally, the monocapped $\mathrm{Mo}\left(\mu_{3}-\mathrm{O}\right)\left(\mu_{2}-\mathrm{O}\right)_{3}$ unit is also common for inorganic clusters. The first documented example containing half-sandwiched metal atoms comes from our own recent study of the chemical reduction of $\mathrm{Cp}^{*}{ }_{2} \mathrm{Mo}_{2} \mathrm{O}_{5}$ by zinc in methanol-water containing $\mathrm{CF}_{3} \mathrm{COOH} .{ }^{[34]}$ The isolated compound contains the $\left[(\mathrm{Cp} * \mathrm{Mo})_{3}\left(\mu_{3}-\mathrm{O}\right)\left(\mu_{2}-\mathrm{O}\right)_{3}\left(\mu_{2}-\mathrm{O}_{2} \mathrm{CCF}_{3}\right)_{3}\right]^{+}$ ion, corresponding to $\mathrm{Mo}_{3}{ }^{\mathrm{V}, \mathrm{V}, \mathrm{V}}$ species.

No trinuclear species containing trifluoroacetate groups was detected in the present study, suggesting that this weakly coordinating anion has a high tendency to remain dissociated in the highly dielectric aqueous medium. The above mentioned isolation of the $\left[\left(\mathrm{Cp}^{*} \mathrm{Mo}\right)_{3} \mathrm{O}_{4}\left(\mathrm{O}_{2} \mathrm{CCF}_{3}\right)_{3}\right]^{+}$ion, on the other hand, suggests the existence of a transient 
$\left[(\mathrm{Cp} * \mathrm{Mo})_{3} \mathrm{O}_{4}\right]^{4+}$ species. Therefore, it is quite likely that a much wider variety of $\left[(\mathrm{Cp} * \mathrm{Mo})_{3} \mathrm{O}_{\mathrm{n}}\right]^{\mathrm{m}+}$ derivatives may be isolated under different $\mathrm{pH}$, solvent, and counterion conditions. It is also likely that these complexes display a very rich redox chemistry. Further synthetic studies are currently ongoing to test these hypotheses and to test the electrofunctionalization of organic substrates for possible catalytic applications.

\section{Conclusion}

The present study has provided new information on the nature of the $\mathrm{Cp}^{*}{ }_{2} \mathrm{Mo}_{2} \mathrm{O}_{5}$ in an aqueous medium and on electrochemical versatility of $\mathrm{Cp}^{*}$ Mo species in water. Selected molecular structure assignments from $m / z$ values and isotopic distributions for $\mathrm{Cp}^{*} \mathrm{Mo}^{\mathrm{V}}$ and $\mathrm{Cp}^{*} \mathrm{Mo}^{\mathrm{IV}}$ reduction products where confirmed by $\mathrm{MS}^{\mathrm{n}}$ fragmentation experiments in comparison with the $\mathrm{Cp} * \mathrm{Mo}^{\mathrm{VI}}$ precursor. The study has shown that the lower $\mathrm{pH}$ conditions established by $\mathrm{CF}_{3} \mathrm{COOH}$ open the access to a $\mathrm{Cp}^{*} \mathrm{Mo}^{\mathrm{III}}$ species, while reduction under acetic conditions went as far down as the oxidation state IV. The study has confirmed the robustness of the $\mathrm{Cp}^{*} \mathrm{Mo}$ bond under aqueous conditions. Even at very low $\mathrm{pH}$, there is no sign or formation of species deriving from the protonolysis of this bond. This feature, together with the proven redox richness of the system, holds promise for potential electrocatalytic applications in an aqueous environment.

\section{Experimental Section}

General Remarks: The starting compounds, $\left(\mathrm{C}_{5} \mathrm{Me}_{5}\right)_{2} \mathrm{Mo}_{2} \mathrm{O}_{5}$ and $\left(\mathrm{C}_{5} \mathrm{Me}_{5}\right)_{2} \mathrm{Mo}_{2} \mathrm{O}_{4}$, were prepared according to the literature procedure. ${ }^{[18]}$ Unless otherwise stated, all solutions of test compounds were prepared in $\mathrm{H}_{2} \mathrm{O} / \mathrm{MeOH}$ mixture (1:1 by volume) containing $0.1 \mathrm{M} \mathrm{CF}_{3} \mathrm{COOH}$. $\mathrm{CF}_{3} \mathrm{COOH}$ was purchased from Aldrich. Methanol HPLC grade was purchased from Baker. The water was triple distilled. 
Electrospray Mass Spectrometry with an Ion Trap: A Finnigan (San Jose, USA) LCQ quadrupole ion trap mass spectrometer equipped with an electrospray ionization (ESI) interface was used for data acquisition. The ESI was operated in the positive ion mode with a spray voltage of $4.5 \mathrm{kV}$, a capillary voltage of $3.5 \mathrm{~V}$, and a source temperature of $120^{\circ} \mathrm{C}$. Mass spectra were obtained by scanning the mass analyzer from $\mathrm{m} / \mathrm{z}, 100$ to 2000 with 5 total microscans. The maximum injection time into the ion trap was $50 \mathrm{~ms}$. The analyzer was operated at a background pressure of $2 * 10^{-5}$ Torr. In all experiments, helium was introduced at an estimated pressure of 1 mTorr to improve the ion trapping efficiency. The background helium also served as collision gas during collision-activated decomposition events. The compounds were isolated in the ion trap with isolation width of 15 $\mathrm{m} / \mathrm{z}$ units and activated by using increased collision energy to obtain collision-energy-dissociation profiles.

Coupled Electrochemistry - Electrospray Mass Spectrometry: The electrochemical part of experimental set up consisted of a PARC 273 potentiostat/galvanostat (Princeton, USA), connected to a specially designed flowthrough electrochemical cell that has been described and characterized elsewhere. ${ }^{[35]}$ The schematic of the electrochemical flow cell is shown in Figure 10. The working glassy carbon disk electrode (1) (Metrohm, Herisau, Switzerland), is placed on the bottom of the cell. Compartments of counter (2) and reference (3) electrodes were separated from the main flow of electrolyte by filters (Upchurch Scientific, Oak Harbor, WA, USA). Both electrodes were $\mathrm{Ag} / \mathrm{AgCl}-1 \mathrm{M} \mathrm{KCl}$. All reported potentials are given relative to the reference electrode. The analyte stream arrives on the working electrode surface through the outer tube (4) of the two coaxial system and the products of the electrode reaction are transferred to the mass spectrometer through the inner tube (5). The distance between the opening of the coaxial system and the working electrode was $50 \mu \mathrm{m}$. All tubes were from PEEK (Upchurch Scientific, Oak Harbor, WA, USA). The inner tube was $125 \mu$ m inner diameter, $1.6 \mathrm{~mm}$ outer diameter, $15 \mathrm{~cm}$ long. The solution flow was driven by a syringe pump. The product stream was diluted with excess methanol. After mixing with methanol, the sample stream was delivered to the ESI interface by a $30 \mathrm{~cm}$ long, $125 \mu \mathrm{m}$ inner diameter tubing. The flow rate of the product stream was $\mathrm{ca} 35$ $\mu 1^{*} \min ^{-1}$. The methanol flow in the auxiliary tubing was $30 \mu \mathrm{min}^{-1}$. The reagent flow rate was set to $5 \mu 1 \min ^{-1}$. Current cell design permitted us to measure mass spectrograms and linear sweep voltammograms simultaneously.

$<$ Figure 10>

\section{Acknowledgments}

RP thanks the CNRS and the Ministry of Research for funding. ADM and OL acknowledge the financial support of the Israel Science Foundation. We are grateful to the French Embassy in Israel for an Arc-en-Ciel/Keshet travel grant and to Prof. M. Vorotyntsev for helpful discussion. We thank a reviewer for most useful comments. 


\section{References}

[1] M. Yamashita, J. B. Fenn, J. Phys. Chem. 1984, 88, 4451-4459.

[2] I. I. Stewart, Spectrochim. Acta, Part B 1999, 54, 1649-1695.

[3] X. W. Wei, Z. Xu, Chin. J. Org. Chem. 1999, 19, 97-103.

[4] J. C. Traeger, Int. J. Mass Spectr. 2000, 200, 387-401.

[5] M. L. Vestal, Mass Spectrom. Rev. 1983, 2, 447-480.

[6] W. F. Smyth, Trac-Trends Anal. Chem. 1999, 18, 335-346.

[7] G. Wolfbauer, A. M. Bond, D. R. MacFarlane, J. Chem. Soc., Dalton Trans. 1999, 4363-4372.

[8] A. M. Bond, R. Colton, D. G. Humphrey, P. J. Mahon, G. A. Snook, V. Tedesco, J. N. Walter, Organometallics 1998, 17, 2977-2985.

[9] X. Xu, W. Lu, R. B. Cole, Anal. Chem. 1996, 68, 4244-4253.

[10] W. Lu, X. Xu, R. B. Cole, Anal. Chem. 1997, 69, 2478-2484.

[11] F. Zhou, G. J. Van Berkel, Anal. Chem. 1995, 67, 3643-3649.

[12] H. Deng, G. J. Van Berkel, Anal. Chem. 1999, 71, 4284-4293.

[13] M. C. S. Regino, A. BrajterToth, Electroanalysis 1999, 11, 374-379.

[14] J. Gun, A. Modestov, O. Lev, D. Saurenz, M. A. Vorotyntsev, R. Poli, Eur. J. Inorg. Chem. in press.

[15] F. Demirhan, P. Richard, R. Poli, Inorg. Chim. Acta in press.

[16] H. Arzoumanian, A. Baldy, M. Pierrot, M. Petrignani, J. Organometal. Chem. 1985, 294, 327-331.

[17] E. de Jesus, A. Vazquez de Miguel, P. Royo, A. M. M. Lanfredi, A. Tiripicchio, J. Chem. Soc., Dalton Trans. 1990, 2779-2784.

[18] D. Saurenz, F. Demirhan, P. Richard, R. Poli, H. Sitzmann, Eur. J. Inorg. Chem. 2002, 1415-1424.

[19] E. J. Alvarez, V. H. Vartanian, J. S. Brodbelt, Anal. Chem. 1997, 69, 1147-1155.

[20] M. J. Van Stipdonk, M. P. Ince, B. A. Perera, J. A. Martin, Rapid Commun. Mass Spectr. 2002, 16, 355-363.

[21] A. J. Gordon, R. A. Ford, 'The Chemist's Companion. Handbook of Practical Data, Techniques and References', J. Wiley and Sons, 1983.

[22] W. C. Byrdwell, W. E. Neff, Rapid Commun. Mass Spectr. 2002, 16, 300-319.

[23] A. K. Vrkic, R. A. J. O'Hair, Int. J. Mass Spectr. 2002, 218, 131-160.

[24] E. Collange, J. Garcia, R. Poli, New J. Chem. 2002, 26, 1249-1256.

[25] M. Cousins, M. L. H. Green, J. Chem. Soc. (A) 1969, 16-19.

[26] A. L. Rheingold, J. R. Harper, J. Organometal. Chem. 1991, 403, 335-344.

[27] V. F. DeTuri, K. M. Ervin, J. Phys. Chem. A 1999, 103, 6911-6920.

[28] E. R. Talaty, B. A. Perera, A. L. Gallardo, J. M. Barr, M. J. Van Stipdonk, J. Phys. Chem. A 2001, 105, 8059-8068.

[29] K. X. Wan, M. L. Gross, T. Shibue, J. Am. Soc. Mass Spec. 2000, 11, 450-457.

[30] J. F. Gal, P. C. Maria, E. D. Raczynska, J. Mass Spectrom. 2001, 36, 699-716.

[31] L. Fan, M. L. Turner, M. B. Hursthouse, K. M. A. Malik, O. V. Gusev, P. M. Maitlis, J. Am. Chem. Soc. 1994, 116, 385-386.

[32] F. Bottomley, J. Chen, K. F. Preston, R. C. Thompson, J. Am. Chem. Soc. 1994, 116, 7989-7995.

[33] J. R. Harper, A. L. Rheingold, J. Am. Chem. Soc. 1990, 112, 4037-4038. 
[34] F. Demirhan, J. Gun, O. Lev, A. Modestov, R. Poli, P. Richard, J. Chem. Soc, Dalton Trans. 2002, 2109-2111.

[35] A. Modestov, J. Gun, O. Lev, in preparation. 

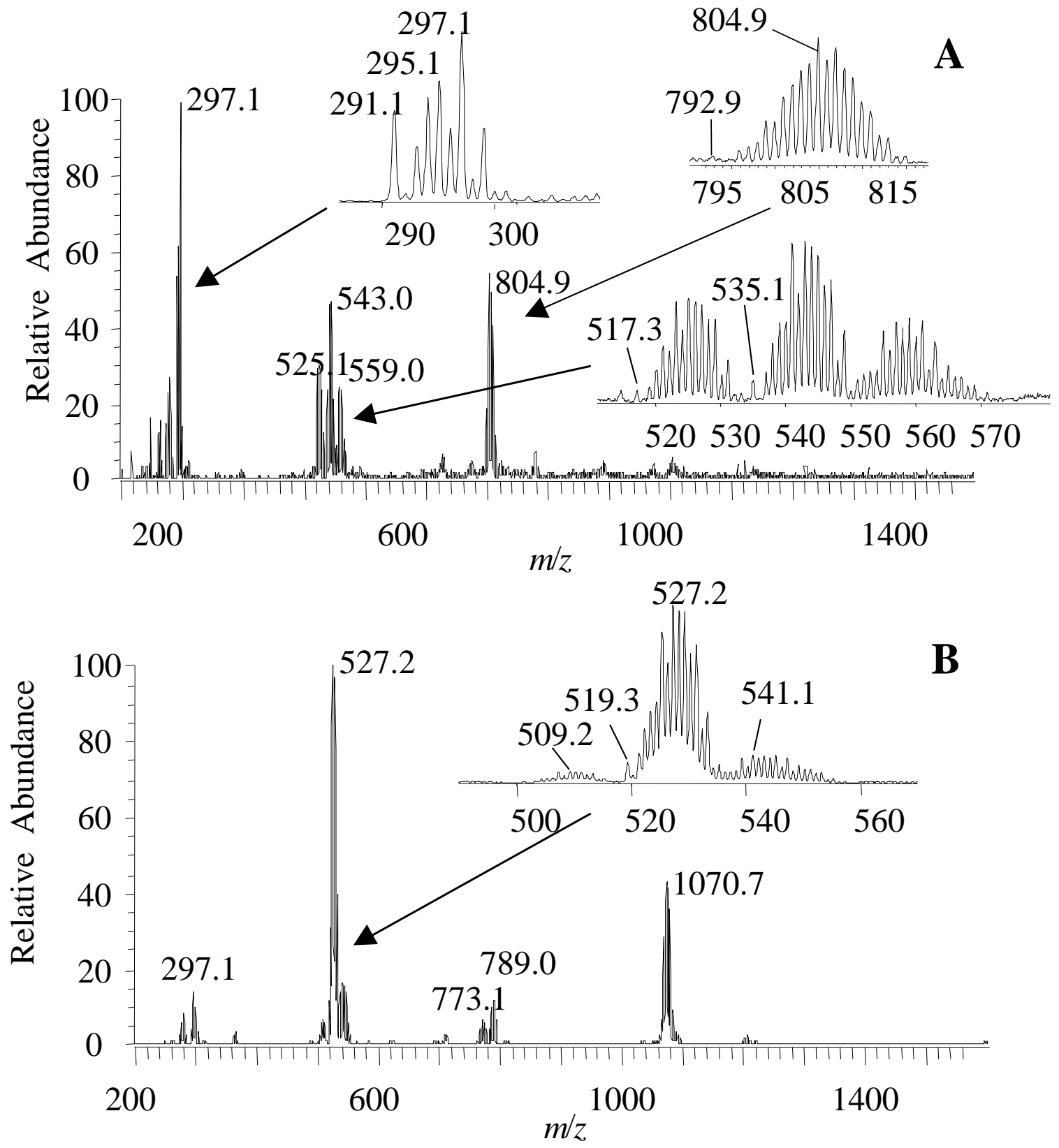

Figure 1. Positive mode electrospray mass spectra in $0.1 \mathrm{M} \mathrm{CF}_{3} \mathrm{COOH}$ in $\mathrm{H}_{2} \mathrm{O} / \mathrm{MeOH}(1: 1)$ $(\mathrm{pH} 1.2)$ of: (A) $\mathrm{Cp}_{2}{ }_{2} \mathrm{Mo}_{2} \mathrm{O}_{5}(0.1 \mathrm{mM})$ and (B) $\mathrm{Cp}_{2}{ }_{2} \mathrm{Mo}_{2} \mathrm{O}_{4}(0.1 \mathrm{mM})$. 


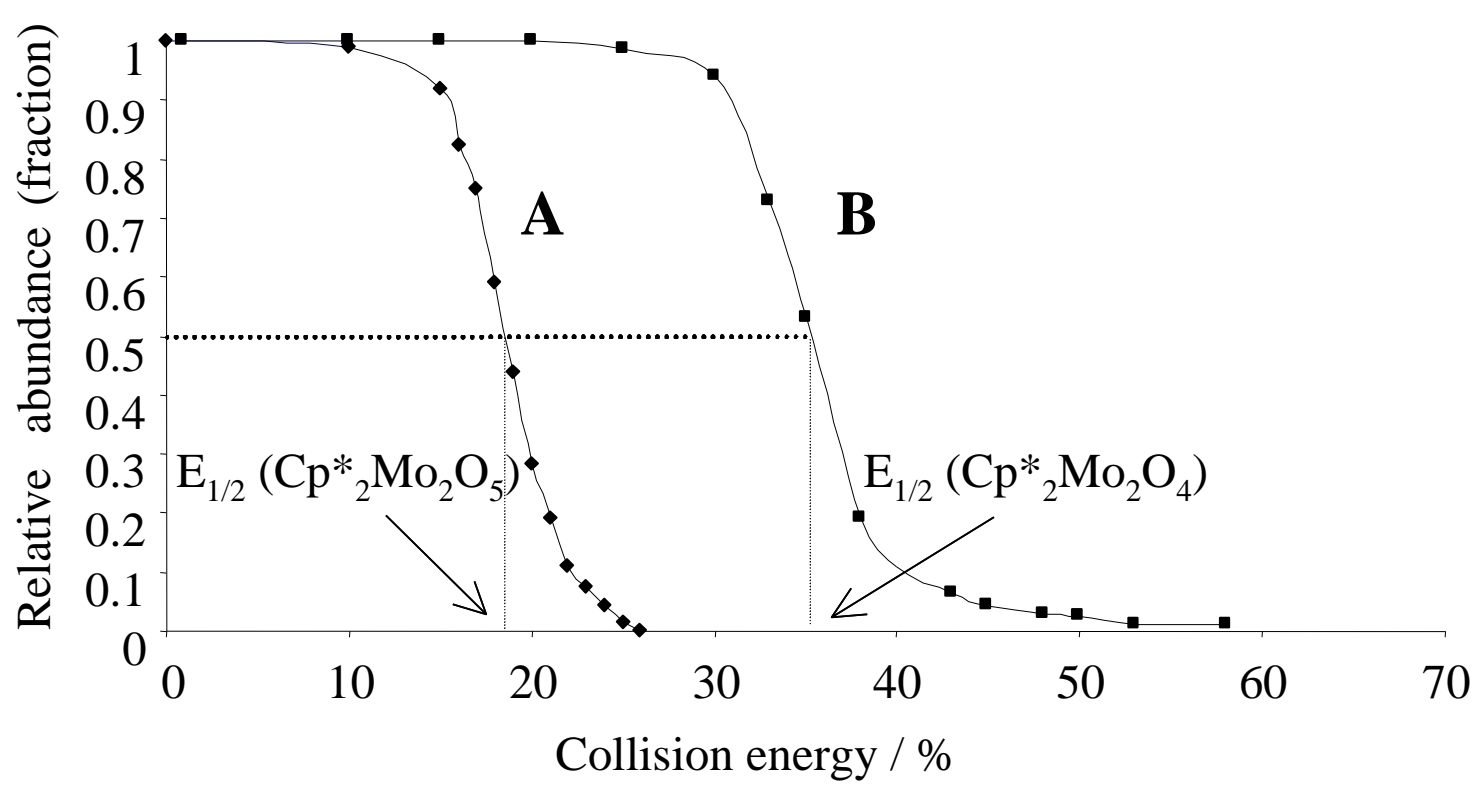

Figure 2. Dissociation profiles of the starting compounds ((A) $\mathrm{Cp}^{*}{ }_{2} \mathrm{Mo}_{2} \mathrm{O}_{5}$ and (B) $\left.\mathrm{Cp}_{2}{ }_{2} \mathrm{Mo}_{2} \mathrm{O}_{4}\right)$ in the same charge state as a function of the increased collision energy in the ion trap. The solutions are as described in Figure 1. 


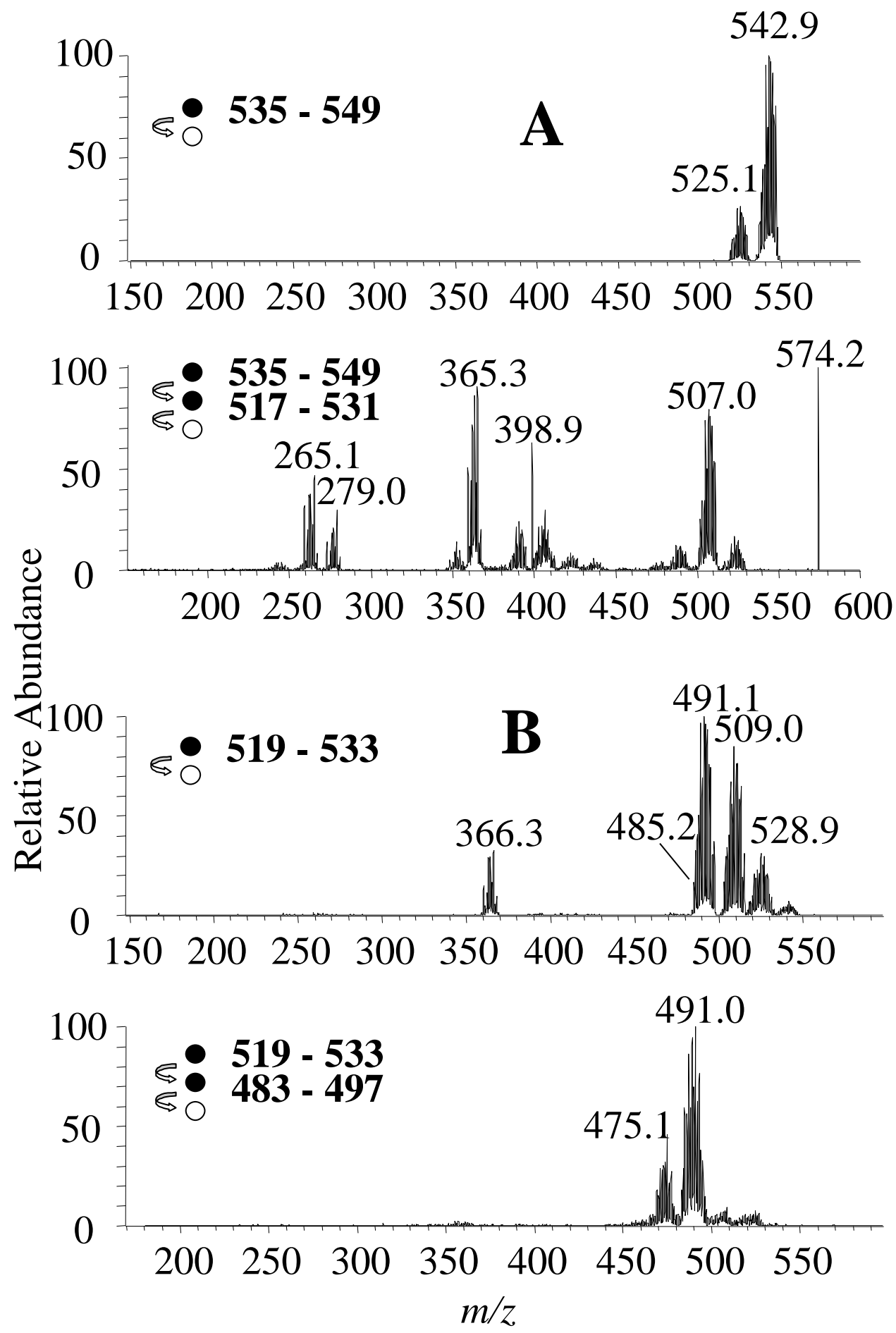

Figure 3. $\mathrm{MS}^{\mathrm{n}}$ fragmentation pathways of $\mathrm{Cp}_{2}{ }_{2} \mathrm{Mo}_{2} \mathrm{O}_{5}(\mathrm{~A})$ and $\mathrm{Cp}_{2}{ }_{2} \mathrm{Mo}_{2} \mathrm{O}_{4}(\mathrm{~B})$ compounds. The solutions are equal to those ascribed in Figure 1. 


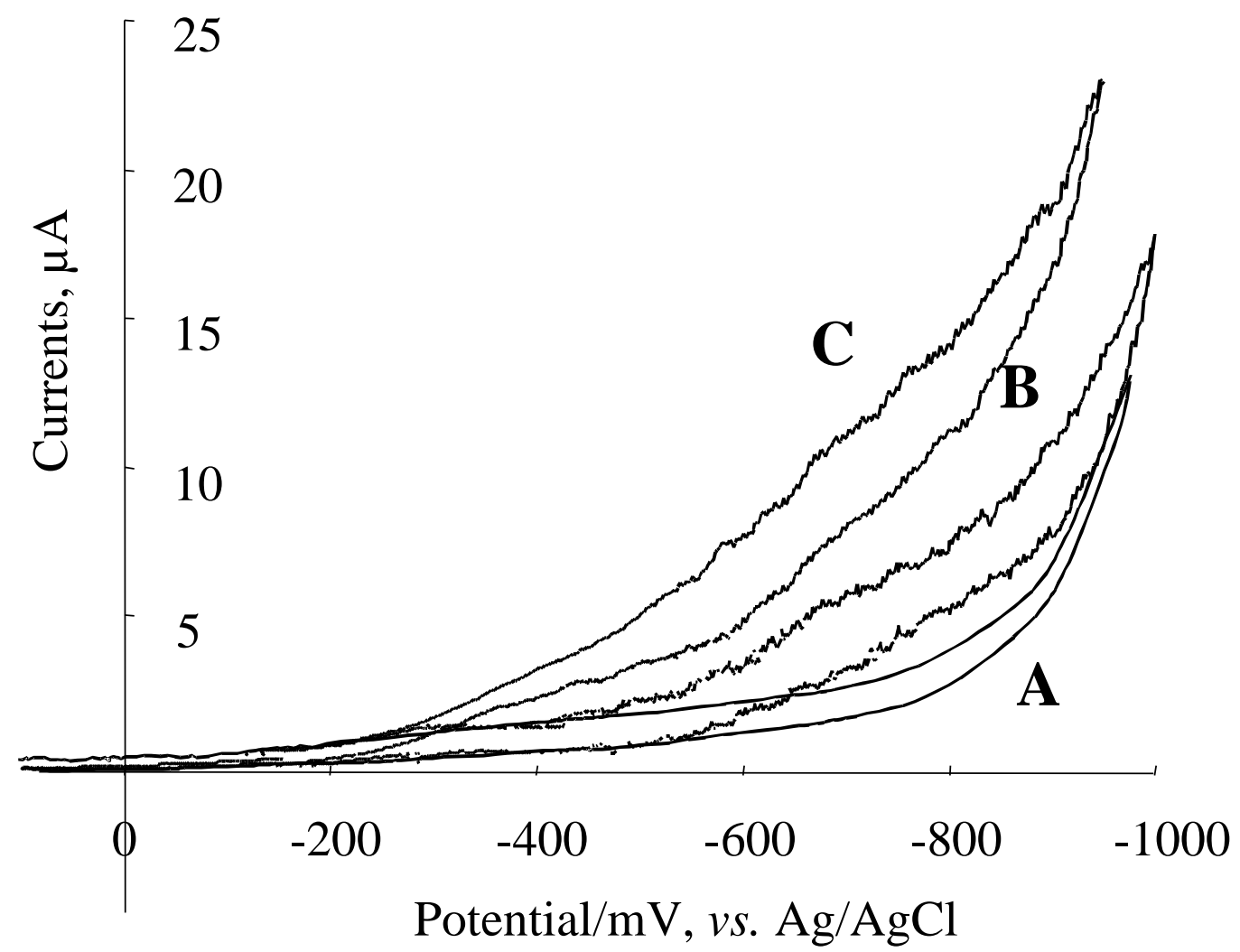

Figure 4. Cyclic voltammograms taken during the on-line combined EC/ESI-MS experiments of: (a) blank solution; (b) $1.1 \mathrm{mM} \mathrm{Cp}{ }_{2} \mathrm{Mo}_{2} \mathrm{O}_{4}$. (c) $1.1 \mathrm{mM}$ $\mathrm{Cp}_{2}{ }_{2} \mathrm{Mo}_{2} \mathrm{O}_{5}$; in $\mathrm{H}_{2} \mathrm{O} / \mathrm{MeOH}(1: 1)$ containing $\mathrm{CF}_{3} \mathrm{COOH}(0.1 \mathrm{M}$; pH 1.2). Scan rate: $0.5 \mathrm{mV} / \mathrm{s}$. 


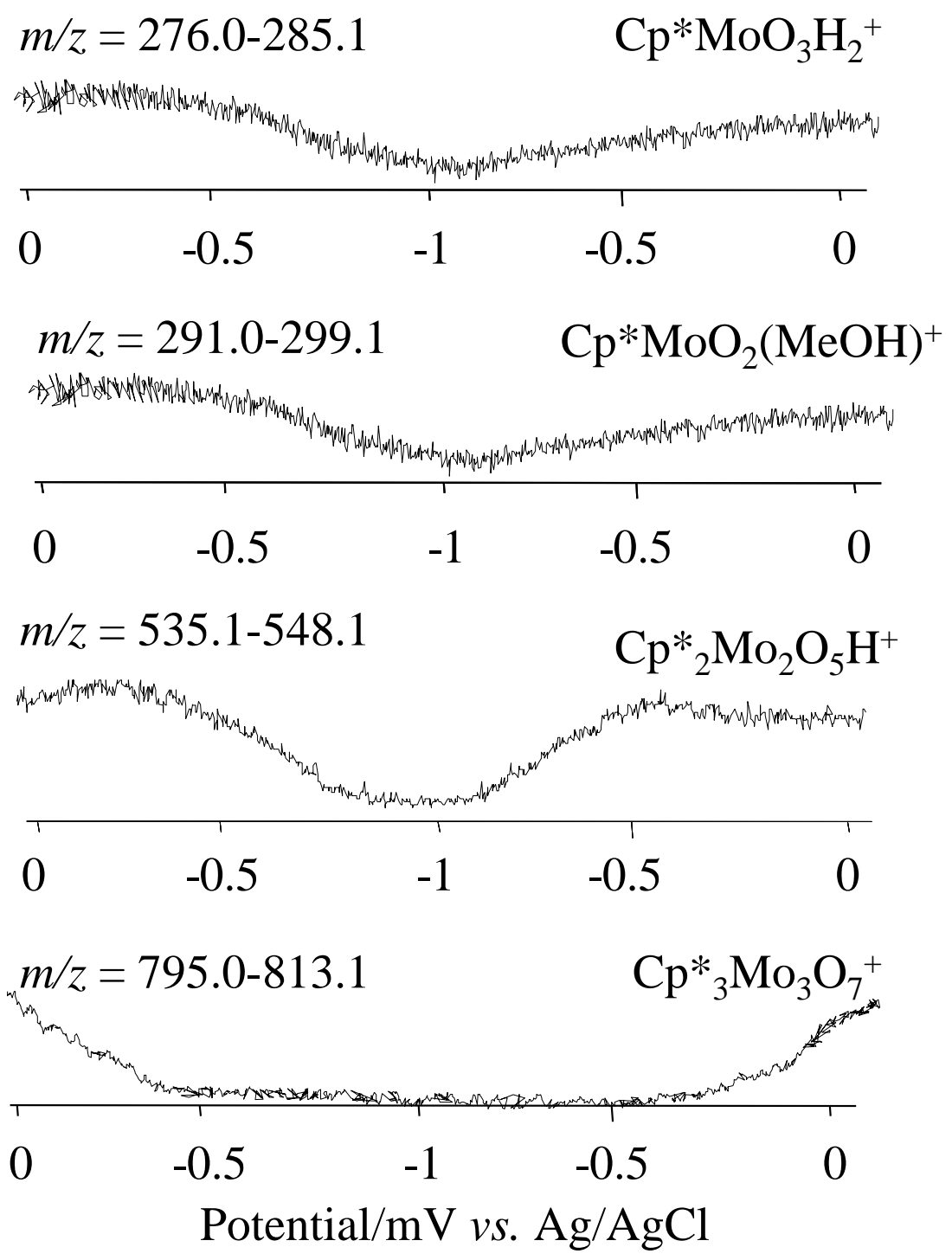

Figure 5. Potential dependence of the relative abundance of the starting species during the coupled electrochemistry - ESI-MS of Cp* ${ }_{2} \mathrm{Mo}_{2} \mathrm{O}_{5}$. The experimental conditions are equal to those described in Figure 4. 


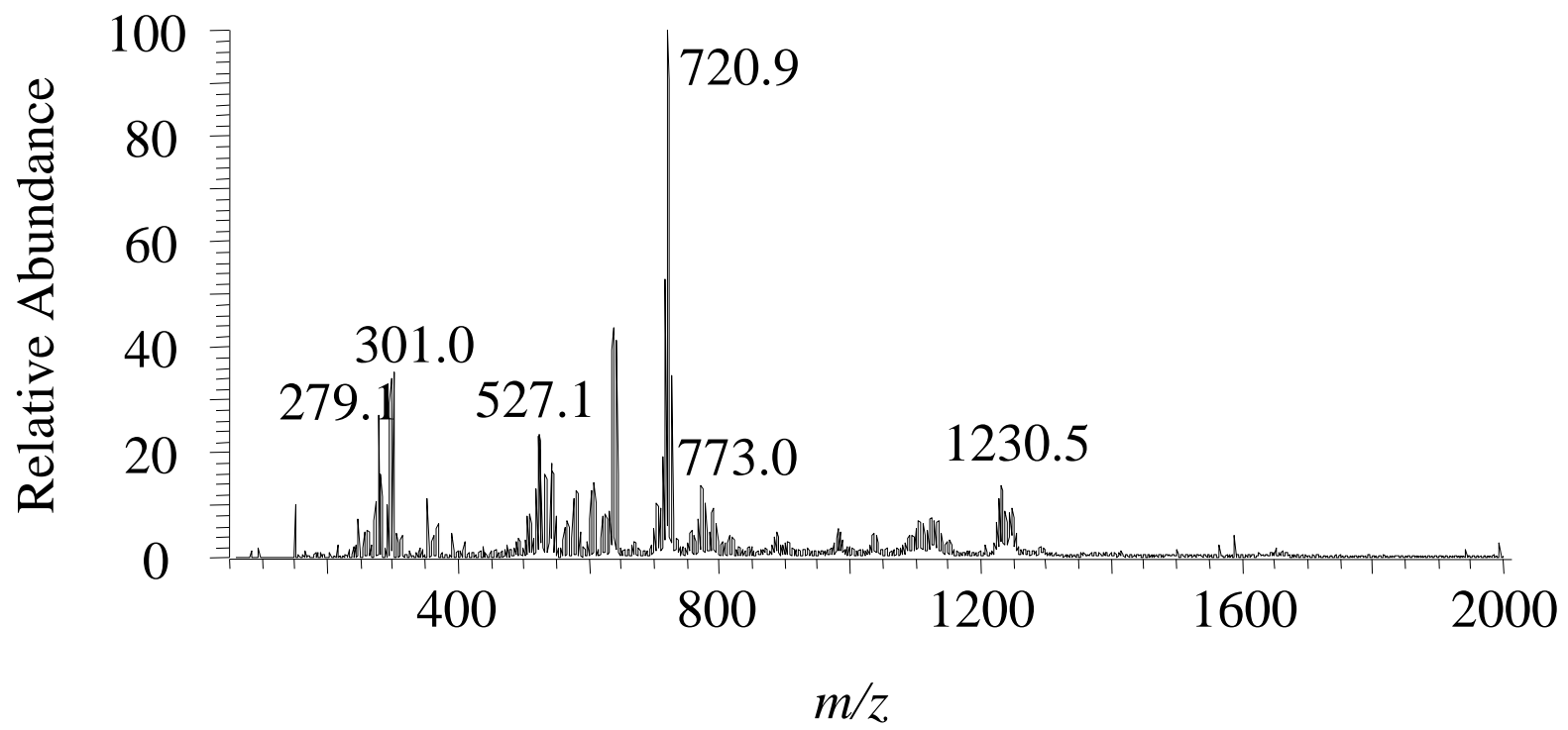

Figure 6. Positive mode electrospray mass spectra in $0.28 \mathrm{M} \mathrm{CF}_{3} \mathrm{COOH}, \mathrm{H}_{2} \mathrm{O} / \mathrm{MeOH}(1: 1)$ $\left(\mathrm{pH}\right.$ 1.2) of $\mathrm{Cp}_{2}{ }_{2} \mathrm{Mo}_{2} \mathrm{O}_{5}(1.1 \mathrm{mM})$ after reduction $(\mathrm{E}=-1 \mathrm{~V})$. 

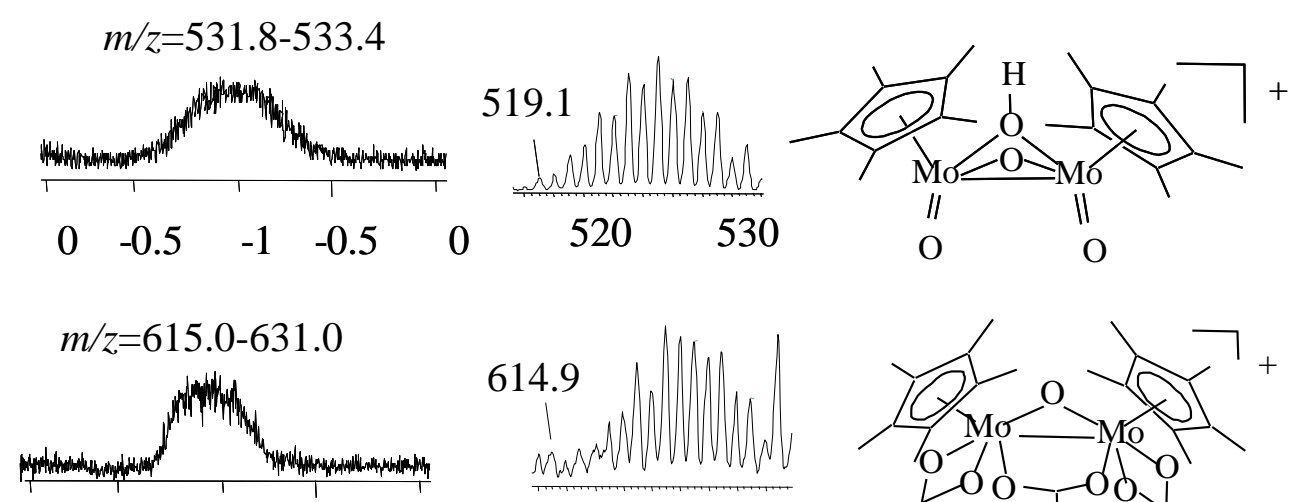

$\begin{array}{lllll}0 & -0.5 & -1 & -0.5 & 0\end{array}$
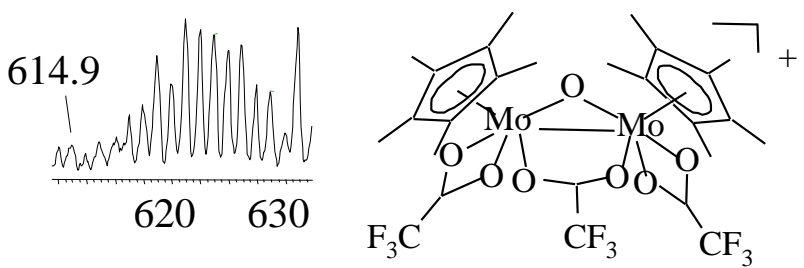

$m / z=712.6-727.3$
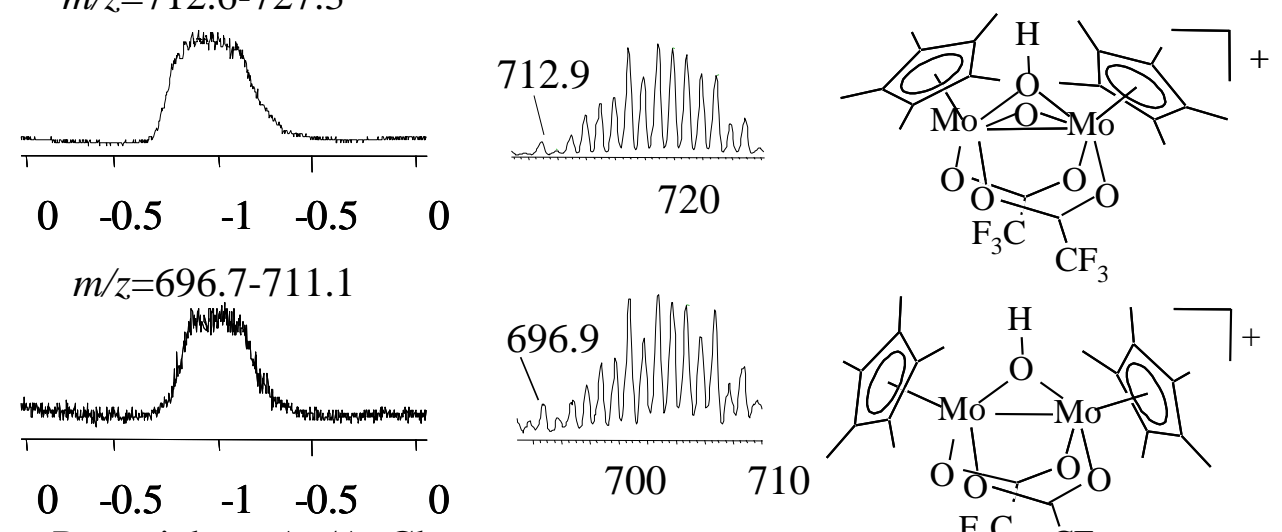

Potential vs. $\mathrm{Ag} / \mathrm{AgCl}$
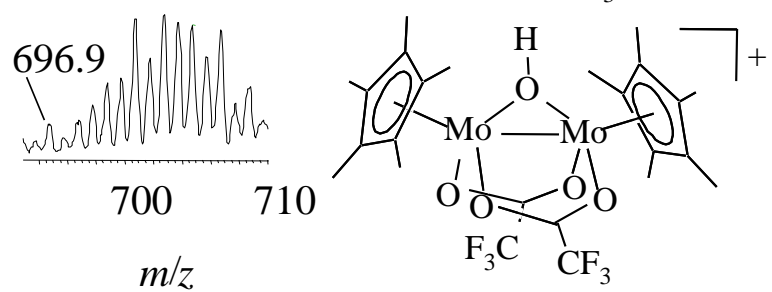

Figure 7. Potential dependence of the relative abundance of the dinuclear species generated during the coupled electrochemistry - ESI-MS of $\mathrm{Cp}_{2}{ }_{2} \mathrm{Mo}_{2} \mathrm{O}_{5}$. Left: Volt-spectrograms with the range of $\mathrm{m} / \mathrm{z}$ used for the integration. Center: expanded isotopic pattern. Right: tentative chemical structure. The experimental conditions are identical with those of Figure 4. 


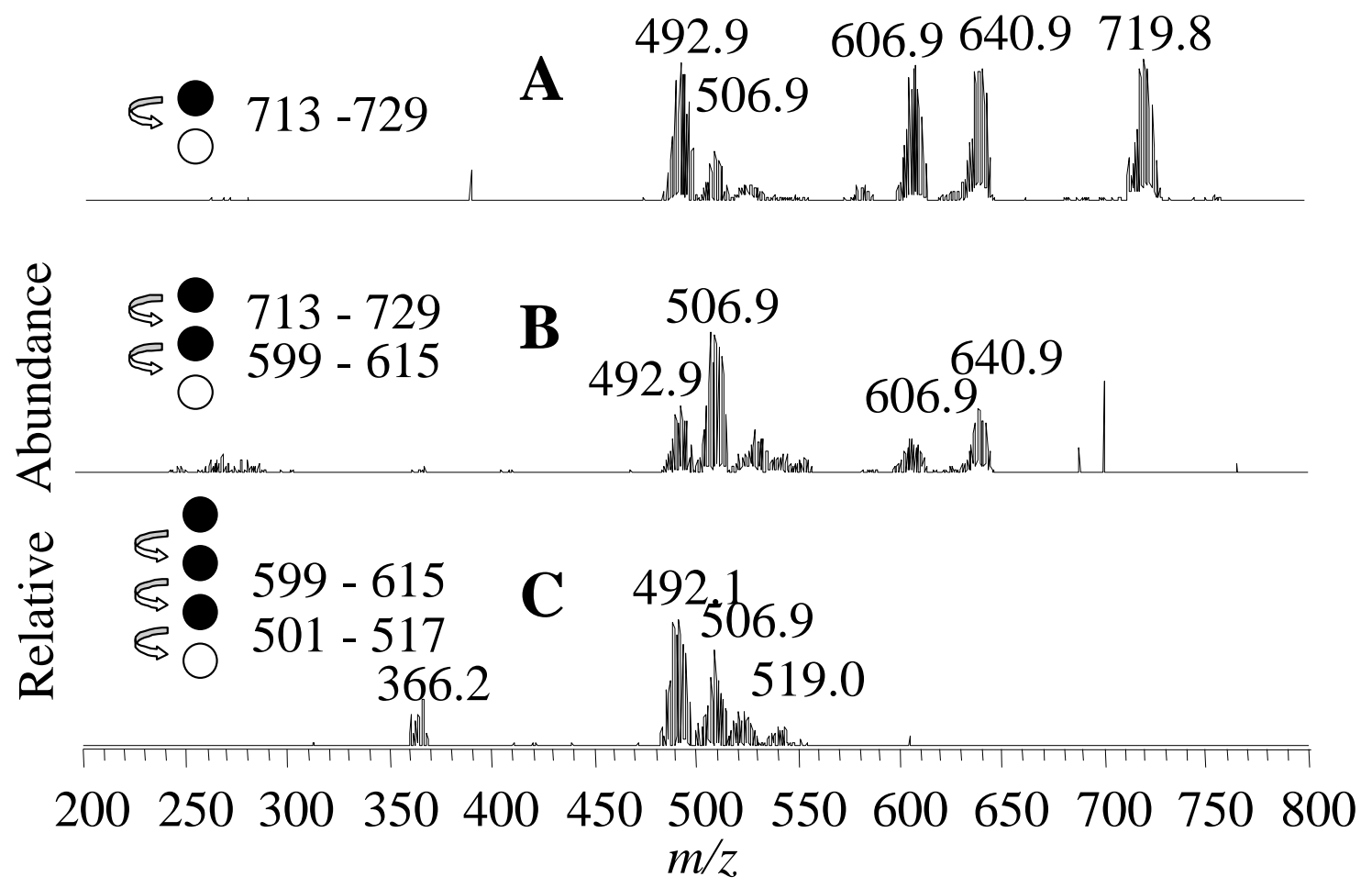

Figure 8. $\mathrm{MS}^{\mathrm{n}}$ structural elucidation of the main product $(\mathrm{m} / \mathrm{z}=713-729)$ of the $\mathrm{Cp}^{*}{ }_{2} \mathrm{Mo}_{2} \mathrm{O}_{5}$ and $\mathrm{Cp}_{2}{ }_{2} \mathrm{Mo}_{2} \mathrm{O}_{4}$ reduction. 


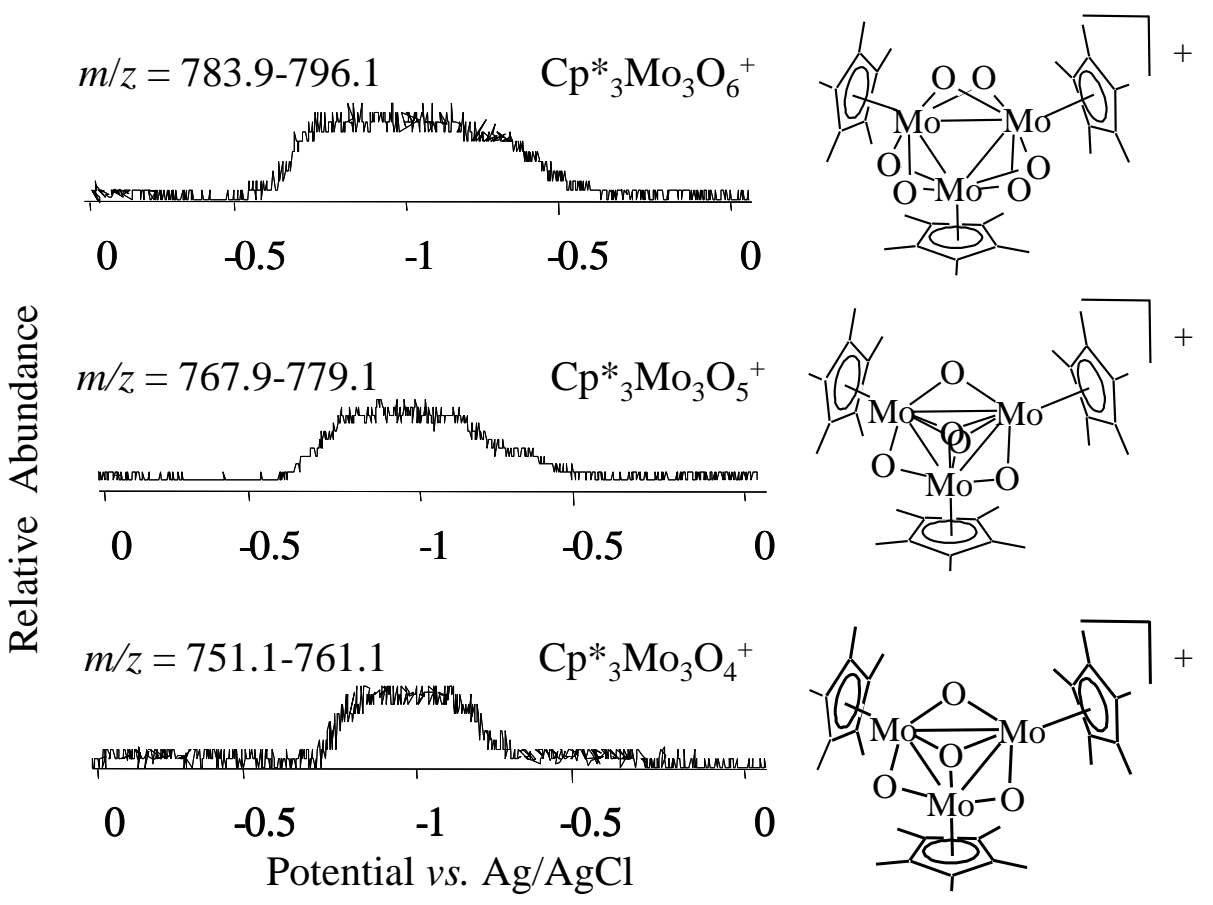

Figure 9. Volt-spectrograms of trimeric species generated during the coupled electrochemistry - ESI-MS of $\mathrm{Cp}^{*}{ }_{2} \mathrm{Mo}_{2} \mathrm{O}_{5}$, including the $\mathrm{m} / \mathrm{z}$ range used for the integration and the chemical formula. The experimental conditions are the same as in Figure 4. 
to MS

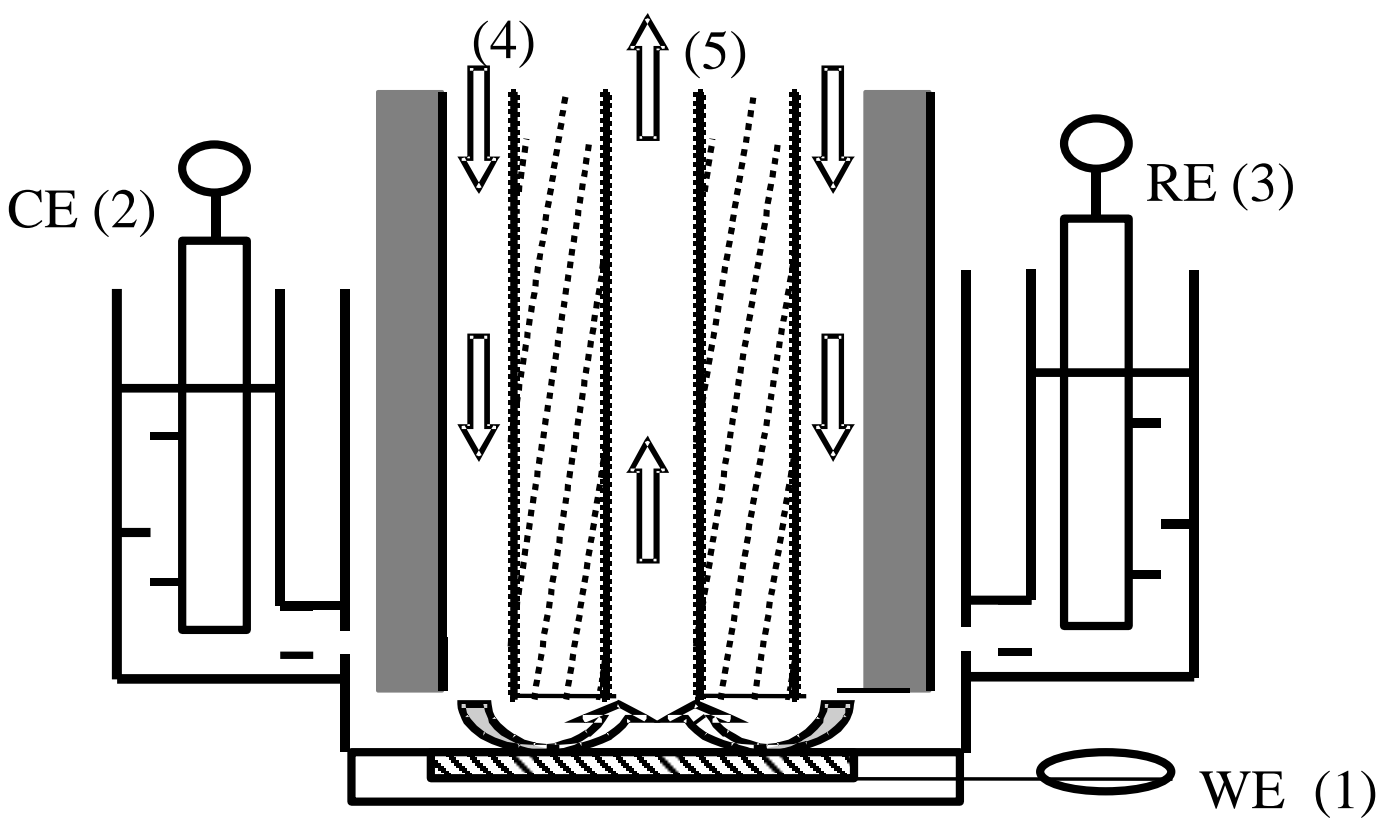

Figure 10. Scheme of the electrochemical cell used in this study.1 - working electrode (WE); 2 - counter electrode (CE), 3 - reference electrode (RE), 4 - outer capillary (transfer line of reagents to working electrode; 5 - inner capillary (transfer line of products to the ESI/MS)). 
Scheme 1

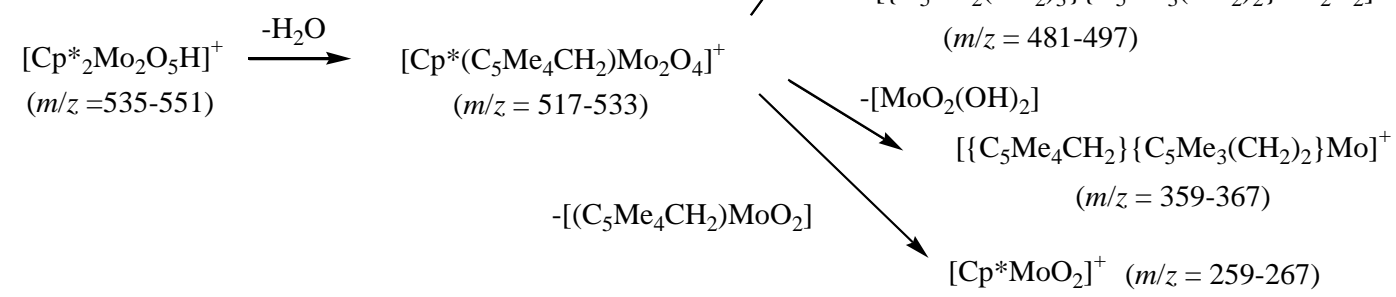

\section{Scheme 2}

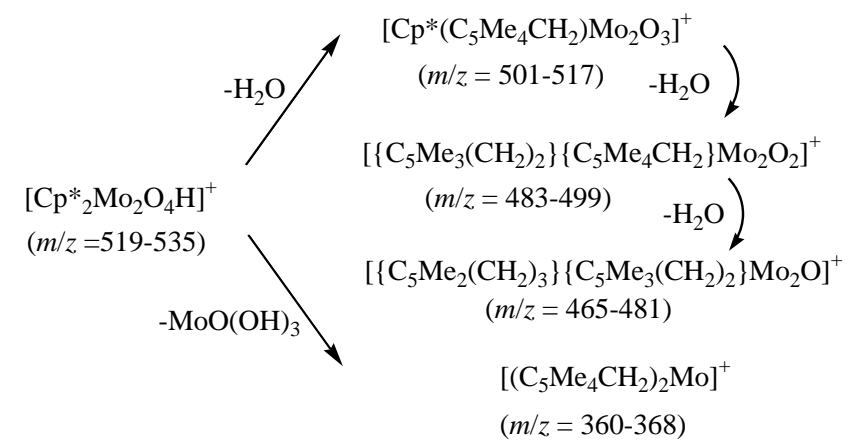

Scheme 3

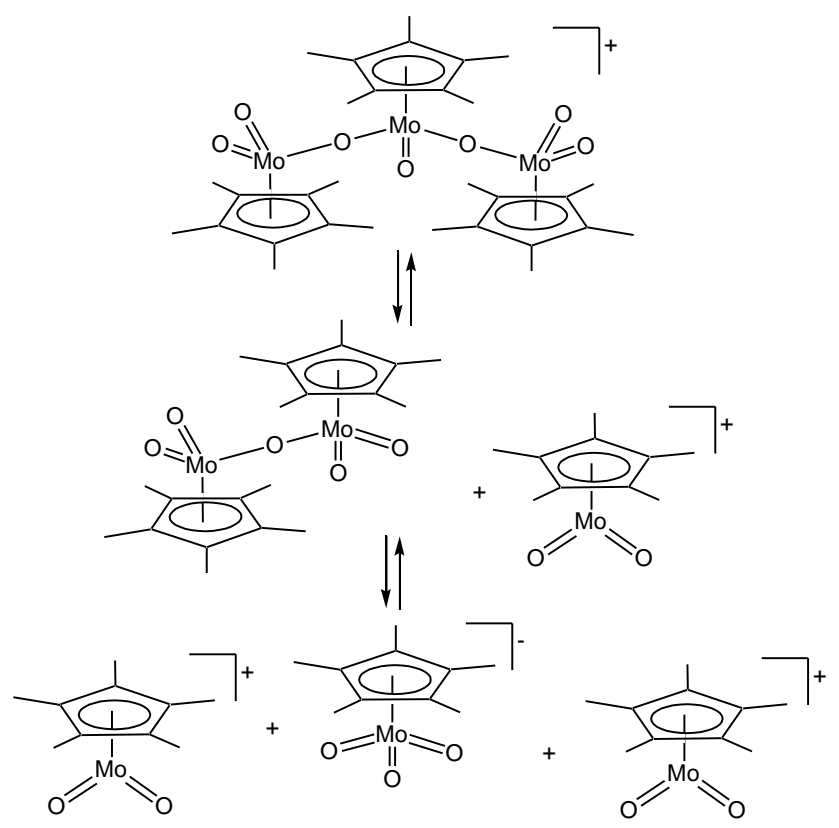




\section{Scheme 4}

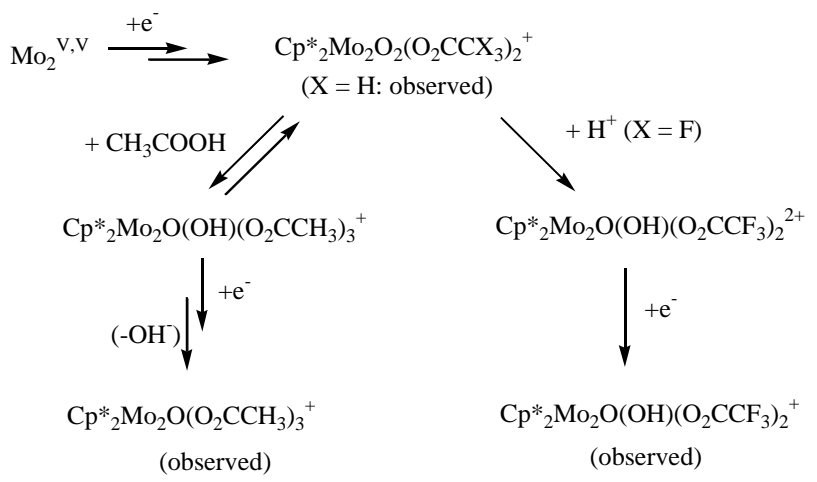

\section{Scheme 5}

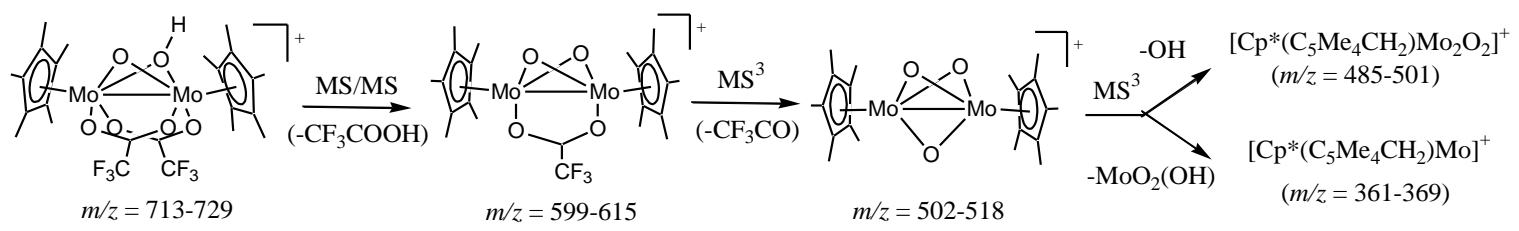


Graphical Content Entry

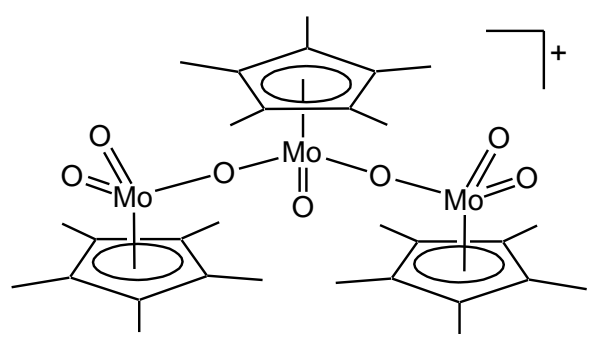

\section{Graphical Abstract}

An electrospray ionisation mass spectrometric analysis coupled on line to a flow through electrochemical shows that the aqueous reduction chemistry at $\mathrm{pH} 1.8$ for compounds $\mathrm{Cp}_{2}{ }_{2} \mathrm{Mo}_{2} \mathrm{O}_{5}$ and $\mathrm{Cp}^{*}{ }_{2} \mathrm{Mo}_{2} \mathrm{O}_{4}$ is identical, whereas differences are noted relative to the same study at $\mathrm{pH} 4.0$. 